\title{
Filling the Gondwanan gap: paleobiogeographic implications of new crinoids from the Castillejo and Fombuena formations (Middle and Upper Ordovician, Iberian Chains, Spain)
}

\author{
Selina R. Cole, ${ }^{1}$ William I. Ausich, ${ }^{1}$ Jorge Colmenar, ${ }^{2}$ and Samuel Zamora ${ }^{3,4}$ \\ ${ }^{1}$ School of Earth Sciences, The Ohio State University, Columbus, OH 43210, USA 〈cole.678@ osu.edu〉; 〈ausich.1@ osu.edu〉 \\ ${ }^{2}$ Natural History Museum of Denmark, University of Copenhagen, Øster Voldgade 5-7, 1350, Copenhagen, Denmark \\ 〈jorgecolmenarlallena@gmail.com〉 \\ ${ }^{3}$ Instituto Geológico y Minero de España, C/Manuel Lasala, 44, 9³, 50006, Zaragoza, Spain〈s.zamora@igme.es〉 \\ ${ }^{4}$ Department of Paleobiology, National Museum of Natural History, Smithsonian Institution, Washington, DC 20013-7012, USA
}

\begin{abstract}
A diverse crinoid fauna is described from the Upper Ordovician (Katian) Fombuena Formation from the eastern Iberian Chains of Spain. New crinoids include the diplobathrid camerates Fombuenacrinus nodulus n. gen. n. sp., Goyacrinus gutierrezi n. gen. n. sp., Dalicrinus hammanni n. gen. n. sp., and Ambonacrinus decorus n. gen. n. sp.; the monobathrid camerate Eopatelliocrinus hispaniensis n. sp.; and the cladid Picassocrinus villasi n. gen. n. sp. A new occurrence of Heviacrinus melendezi Gil Cid, Domínguez Alonso, and Silván Pobes, 1996 is also documented from the Castillejo Formation (Darriwilian, Middle Ordovician) from the eastern Iberian Chains of Spain. The Fombuena Formation comprises a Gondwanan crinoid assemblage from a high paleolatitude and has the highest crinoid diversity of any currently known Katian Gondwanan fauna. This assemblage is compared to other Katian age faunas around the globe, and its paleobiogeographic implications are discussed.
\end{abstract}

\section{Introduction}

The Ordovician was a pivotal time in the evolutionary history of the Crinoidea. The oldest known crinoids are from the earliest Ordovician (early Tremadocian), by which time most major clades of Paleozoic crinoids were already present. By the Floian, crinoids had appeared on most paleocontinents. Current understanding of Ordovician pelmatozoan faunas indicates they were highly endemic during the Early and Middle Ordovician but became more cosmopolitan during the Late Ordovician (Paul, 1976; Lefebvre and Fatka, 2003; Lefebvre et al., 2013). However, interpretations of the paleobiogeographic patterns of crinoids and other pelmatozoans during the Ordovician are inhibited by uneven global sampling. In particular, most Ordovician paleocontinents are undersampled relative to Laurentia, which has likely introduced a Laurentian bias into hypotheses of Ordovician macroevolutionary and paleobiogeographic patterns (Ausich and Kammer, 2011). For this reason, the recovery and description of faunas from non-Laurentian paleocontinents is critical to an improved understanding of the dynamics of both the initial Early Ordovician radiation of crinoids and the subsequent Middle Ordovician radiation (Sprinkle and Guensburg, 2004; Peters and Ausich, 2008) that occurred during the Great Ordovician Biodiversification Event (GOBE; Webby et al., 2004).

Herein, we describe five new crinoid genera and species, one new species of Eopatelliocrinus Brower, 1973, and two taxa left in open nomenclature from the Upper Ordovician (Katian)
Fombuena Formation of northeastern Spain. We also document a new occurrence of Heviacrinus melendezi Gil Cid, Domínguez Alonso, and Silván Pobes, 1996 from the Middle Ordovician (Darriwilian) Castillejo Formation of northeastern Spain. Notably, the Fombuena fauna has the highest taxonomic richness of any Katian crinoid assemblage known from Gondwana and represents a diverse, camerate-dominated fauna from a high-latitude siliciclastic environment. Description of this new fauna serves to improve sampling of underrepresented Middle Ordovician paleocontinents, and comparison to other Katian-age crinoid assemblages enhances interpretations of paleobiogeographic patterns.

\section{Materials and methods}

Collection localities.-The studied crinoid material was collected from three localities in the eastern Iberian Chains of northeastern Spain (Fig. 1). Material collected from the Fombuena Formation came from two localities at the same stratigraphic horizon (Fig. 2). This horizon is located in the Huerva Member of the Fombuena Formation and is middle to early late Berounian (lower to middle Katian, Ka1-2 stage slices) in age (Villas, 1995). Locality 1 is located about $1 \mathrm{~km}$ west of the village of Fombuena $\left(41^{\circ} 8^{\prime} 53^{\prime \prime} \mathrm{N}, 1^{\circ} 12^{\prime} 16^{\prime \prime} \mathrm{W}\right)$ and corresponds to the F4 locality (Peña del Tormo section) of Villas (1985). Locality 2 is located about $2 \mathrm{~km}$ south of the village of Fombuena $\left(41^{\circ} 7^{\prime} 45^{\prime \prime} \mathrm{N}, 1^{\circ} 12^{\prime} 4 \mathrm{~W}\right)$ and corresponds to the F8 locality (Santa Catalina section), RC of Villas (1992). Material 

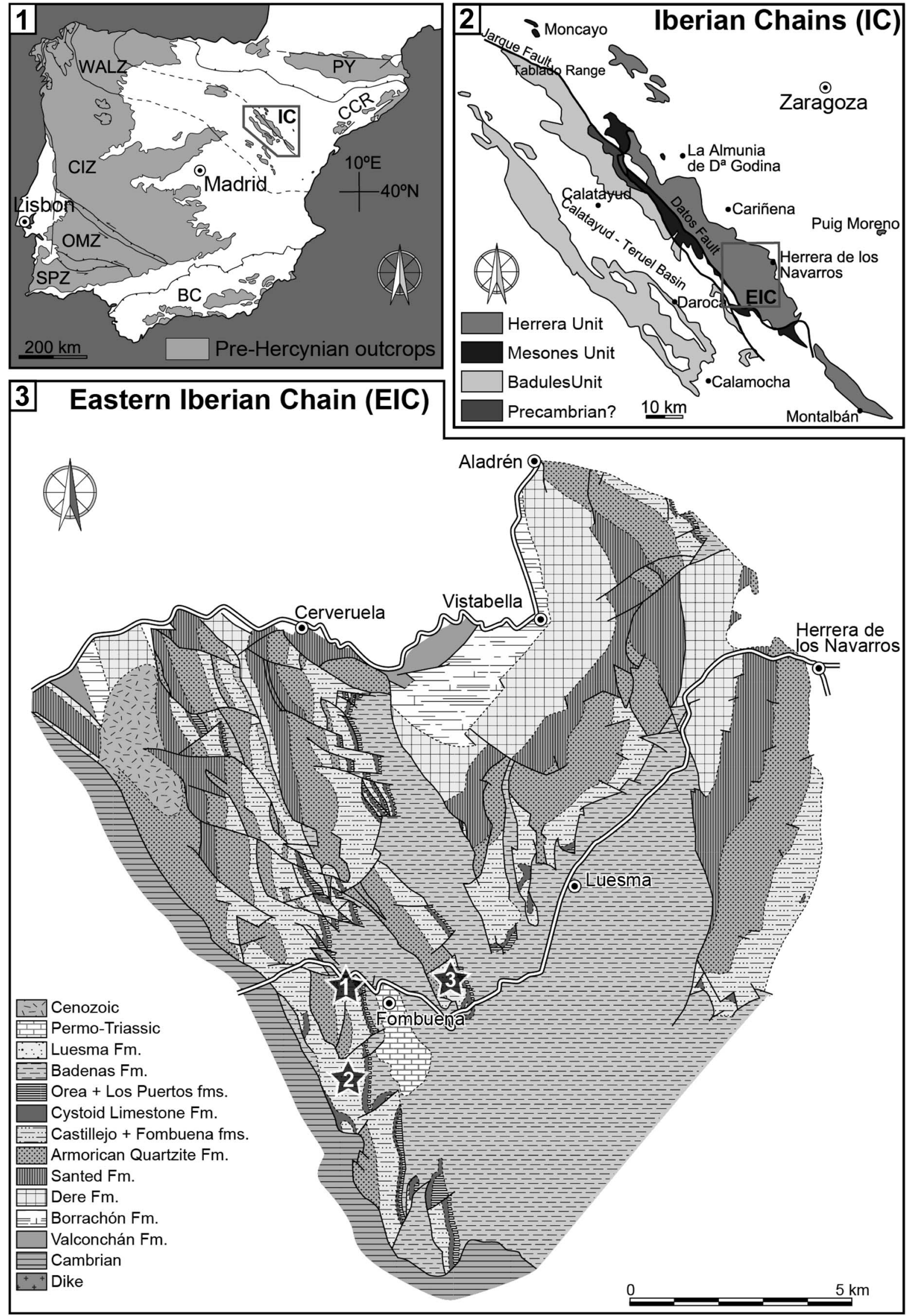

Figure 1. Locality map. (1) Location of the Iberian Chains within Spain; (2) study region within the Iberian Chains; (3) location of collection sites in the eastern Iberian chains. Modified from Hammann (1992) and Zamora et al. (2015a). 


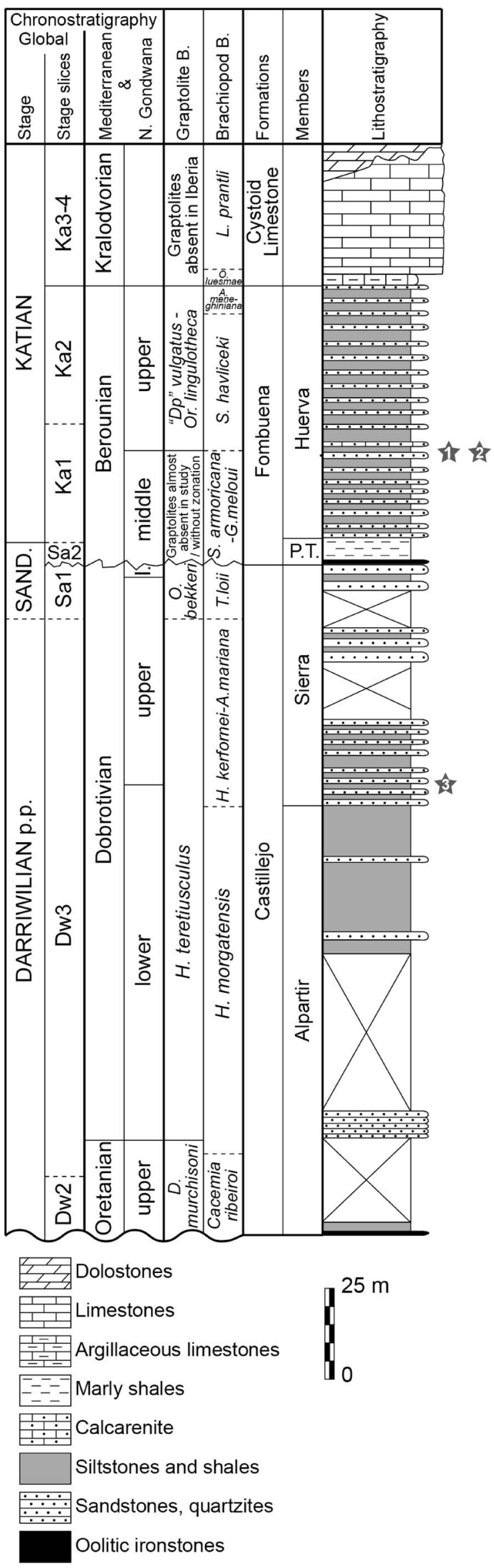

collected from the Castillejo Formation (locality 3 ) is located about $1.5 \mathrm{~km}$ northeast of Fombuena village and corresponds to the F1 locality of Villas (1985). The locality 3 collection horizon is located in the Sierra Member of the Castillejo Formation, which is late Dobrotivian (latest Darriwilian to earliest Sandbian) in age (Hammann et al., 1982; Sarmiento et al., 1995).

Material and repository information.-The recovered crinoid material is preserved as natural external molds. Latex casts made from the specimens were used to study the material. All specimens described herein are deposited in the Museo de Ciencias Naturales de la Universidad de Zaragoza (MPZ), Spain.

\section{Stratigraphy and geologic setting}

The eastern Iberian Chains of northeastern Spain preserve an almost complete Ordovician section that is nearly 4,000 m thick (Figs. 1, 2). The succession is predominantly comprised of siliciclastic rocks, with the exception of $40 \mathrm{~m}$ of Kralodvorian (upper Katian, Ka3-4 stage slices; see Gutiérrez-Marco et al., 2015 for correlation of the Ibero-Bohemian regional scale with the global and British chronostratigraphic scales) limestones and up to $8 \mathrm{~m}$ of middle Berounian (late Sandbian-early Katian) bryozoan marls, and has been the subject of extensive stratigraphic study (Lotze, 1929; Carls, 1975; Wolf, 1980; Villas, 1983; Hammann, 1992; Gutiérrez-Marco et al., 2002, 2005; Sarmiento, 2002; Colmenar, 2015). Only the Castillejo and Fombuena formations have yielded complete articulated crinoids (Fig. 2).

During the Ordovician, the Iberian Chains were located in high latitudes of Gondwana. Until the early Late Ordovician, sedimentation was predominantly siliciclastic in the region. Sedimentation then drastically changed to carbonate dominated after the late Katian global warming Boda event (Fortey and Cocks, 2005). Siliciclastic deposition later resumed in the region during the Hirnantian as a consequence of a cooling event (Rasmussen and Harper, 2011).

Castillejo Formation.-The Castillejo Formation paraconformably overlies the Armorican Quartzite and is divided into three members (Fig. 2). The basal Marité Member ( $1 \mathrm{~m}$ to $40 \mathrm{~m}$ thick) is characterized by ferruginous beds that locally form up to three oolitic ironstone horizons (Carls, 1975). Graptolite biostratigraphy indicates the member is late Oretanian (middle to late Darriwilian) in age (Kolb, 1978; Wolf, 1980; Gutiérrez-Marco, 1986).

The middle Alpartir Member (110-200 m thick) is predominately comprised of shales with some intercalations of sandstones and siliceous and ferruginous nodules. The faunal assemblage includes graptolites, trilobites, and brachiopods, which indicate the Alpartir Member is early Dobrotivian (late Darriwilian) in age (Kolb, 1978; Hammann et al., 1982; Gutiérrez-Marco, 1986).

Figure 2. Middle to Upper Ordovician stratigraphy of the Eastern Iberian Chain indicating collected horizons (stars), correlation with the regional and global chronostratigraphy, and primary brachiopod and graptolite biozones defined in SW Europe. Numbers refer to sites illustrated in Figure 1. Modified from Villas (1985). 
The upper Sierra Member decreases in thickness toward the northwest from $150 \mathrm{~m}$ to $10 \mathrm{~m}$ (Villas, 1983). It is characterized by alternating shales and sandstones that frequently include highly fossiliferous sandstone lenses with calcareous cement. The fauna includes trilobites, gastropods, bivalves, rostrochonchs, conodonts, and brachiopods and indicates the Sierra Member is late Dobrotivian (latest Darriwilian to earliest Sandbian) in age (Hammann et al., 1982; Sarmiento et al., 1995).

Echinoderms from the Castillejo Formation are rare. Diploporitans recovered include Calix rouaulti Chauvel, 1936 and fragmentary material belonging to Aristocystitidae gen. indet. sp. indet. (Carls, 1975; Kolb, 1978; Gutiérrez-Marco et al., 1996). A single complete crinoid specimen assigned herein to Heviacrinus melendezi has been collected from the siltstones of the lower part of the upper Sierra Member of the Castillejo Formation in the Castillejo hill section (Fig. 2, locality 3).

Fombuena Formation.-The Fombuena Formation overlies the Castillejo Formation and is divided into two members (Fig. 2). The lower Piedra del Tormo Member is comprised of a $1 \mathrm{~m}$ thick ooidal ironstone overlain by $8 \mathrm{~m}$ of marly shales and marlstones that contain abundant bryozoans, brachiopods, gastropods, benthic graptolites, and echinoderms. The ironstone is present at the base of the formation throughout the eastern Iberian Chain, but the bryozoan marls are restricted to the vicinity of Fombuena. Brachiopods recorded in the ironstone and the overlying marls allow correlation with distant units in Iberia (Villas, 1992; Villas et al., 2006), and indicate the member is middle Berounian (late Sandbian to early Katian, Sa2-Ka1 stage slices) in age (Paris, 1979, 1981).

The Piedra del Tormo Member is very fossiliferous. The first echinoderms recovered from this member were the rhombiferans Heliocrinites? sampelayanus Meléndez, 1944 and Heliocrinites? isabellae Meléndez, 1944, which were described from poorly preserved specimens. Later, extensive sampling of the same horizons produced a moderately diverse echinoderm fauna that included the coronoid Mespilocystites lemenni Gutiérrez-Marco, Chauvel, and Meléndez, 1996, the diploporans Calix? cf. gutierrezi Chauvel and Meléndez, 1986 and Sphaeronitida fam. indet., and the rhombiferans Caryocrinites cf. rugatus Forbes, 1848, Hemicosmitida fam. indet., Heliocrinites sp., and Rhombifera bohemica Barrande, 1867 (Gutiérrez-Marco et al., 1996).

The Huerva Member, which is also restricted to the Fombuena area, overlies the upper marly horizon of the Piedra del Tormo Member and is comprised of sandstones with interbedded sandy shales. A single fossiliferous horizon (Fig. 2, localities 1 and 2), $20 \mathrm{~m}$ above the base of the unit, has yielded a typical middle to early late Berounian (lower to middle Katian, Ka1-2 stage slices) brachiopod assemblage, echinoderms, and scarce trilobites. The crinoid specimens described herein from localities 1 and 2 were collected from this horizon. Although the stratigraphic position of the fossiliferous horizon of the Huerva Member varies laterally within the unit, fossil content, taphonomy, and preservation are nearly identical at all localities and, thus, are interpreted as correlative horizons (Villas, 1985, 1992). The first echinoderms from this level were described by Gutiérrez-Marco et al. (1996), who reported the rhombiferan Rhombifera sp., the diploporoid Diploporita indet., and the coronoid Mespilocystites lemenni. Samples from the La Peña del Tormo (locality 1) and Santa Catalina hill (locality 2) sections of Fombuena have yielded a remarkably well-preserved echinoderm fauna that was first introduced by Zamora et al. (2014, 2015a), and the crinoid content is formally described herein. Complete crinoid specimens have only been recovered from the fossiliferous horizon of the Huerva Member at these two localities. Higher in the section, occurrence of Dalmanella unguis unguis Sowerby and Murchison, 1839 in the middle horizons of the member suggests correlation with the Marshbrookian (lower Katian, Ka1 stage slice). Finally, the uppermost levels of the Huerva Member have yielded a late Berounian (lower to middle Katian, Ka1-2 stage slices) fauna (Villas, 1995).

Paleoenvironmental interpretations.-Although the sedimentology and sequence stratigraphy of this section has not been studied in detail, general paleoenvironmental interpretations can be made for collection localities based on lithology, taphonomy, and brachiopod assemblages. Both the Castillejo and Fombuena formations are comprised of siliciclastic rocks with fossiliferous horizons being predominantly made up of siltstones. Fossils are well preserved at all collection localities, including very delicate taxa (e.g., ramose bryozoans, asterozoans, and solutes) and articulated echinoderm parts such as diploporan oral plates, crinoid arms, rhombiferan stems, and solute appendages (Zamora et al., 2014). This quality of preservation indicates the fauna experienced rapid burial and minimal transport, most likely from the effects of obrution events such as storms (Brett et al., 1997). In addition, brachiopod assemblages from the sampled localities in both the Castillejo and Fombuena formations (Villas, 1985, 1992) are dominated by heterorthid brachiopods that have been established as valuable proxies for environmental interpretations based on the size and morphology of their ventral muscle field (Colmenar et al., 2013). Specifically, Svobodaina armoricana Babin and Mélou, 1972 in the Fombuena Formation (Villas, 1992) and Heterorthina kerfornei Mélou, 1975 in the Castillejo Formation (Villas, 1985) are indicative of lowenergy environments because of their small ventral muscles. On the basis of these combined lines of evidence, a low-energy offshore environmental setting is inferred for all three collection localities from the fossiliferous horizons of the Fombuena and Castillejo formations.

\section{Katian crinoid faunas of Gondwana and Laurentia}

Overview of Katian crinoid faunas.-Recognition of secular changes in crinoid clade dominance through the Paleozoic has led to the identification of three crinoid faunal assemblages, termed the early, middle, and late Paleozoic crinoid evolutionary faunas (CEF; Ausich et al., 1994; Baumiller, 1994). Different assemblages of crinoid clades typically dominated each of the three evolutionary faunas in terms of both taxonomic diversity and relative abundance. For example, assemblages from the early Paleozoic CEF (Early Ordovician to Katian) were typically dominated by disparids, hybocrinids, and locally diplobathrid camerates. The Late Ordovician extinction triggered the transition to the middle Paleozoic CEF in the early Silurian, which was characterized by monobathrid camerates, 
cladids, and flexibles (Eckert, 1988; Ausich and Deline, 2012). Although these temporally shifting patterns of faunal composition are well recognized, there is a sampling bias of crinoid occurrence data toward Laurentian faunas. Thus, paleobiogeographic changes in these patterns are less thoroughly characterized. In particular, the Katian represents the peak of the early Paleozoic CEF, yet few Gondwanan faunas are known from this interval. This has precluded recognition of any geographic differences in faunal composition.

Among Laurentian Katian faunas, the composition of crinoid assemblages is variable. Although some faunas have a relatively equitable distribution of taxa among clades, in most Laurentian faunas the majority of taxa belong to the disparids or cladids (Table 1). Both diplobathrid and monobathrid camerates are low in diversity in most Katian faunas. Thus, as known from predominantly Laurentian material, the basic clade composition of Katian crinoid faunas had begun to shift toward a composition more similar to faunas of the middle Paleozoic CEF.

Until recently, very few Ordovician crinoids described from crown material were known from Gondwana, and many remain poorly understood taxa (e.g., Vinassa de Regny, 1942; Ubaghs, 1969, 1972). Since 1988, several new faunas have been reported, including crinoids from Argentina (Guensburg and Waisfeld, 2015), France (Lefebvre et al., 2015), Morocco (Donovan and Savill, 1988; Le Menn and Spjeldnaes, 1996; Zamora et al., 2015b), Oman (Donovan et al., 2011), Portugal (Ausich et al., 2007; Correia and Loureiro, 2009), and Spain (Gil Cid et al., 1996, 1998; Ausich et al., 2002, 2007). Of these Ordovician Gondwanan faunas, two are Katian in age. Crinoid taxa known from these Katian Gondwanan faunas include Rosfacrinus Le Menn and Spjeldnaes, 1996 from Morocco and Visocrinus Ausich, Gil Cid, and Domínguez Alonso, 2002 from Spain. Gondwanan Katian faunas with the highest crinoid biodiversity are the Fombuena Formation fauna of Spain, described here, and the Portixeddu Formation fauna of Sardinia. The latter has not yet been formally described, but preliminary work indicates crinoids are relatively diverse, containing anthracocrinid and rhodocrinitid diplobathrids, homocrinid and maennilicrinid disparids, and dendrocrinid cladids (Sumrall et al., 2015).

Fombuena Formation fauna: characteristics and implications.-Because the Fombuena Formation fauna is the first Katian Gondwanan assemblage from which multiple identifiable crinoid specimens have been recovered, it enhances interpretation of the diversification history, faunal characteristics, and paleoecological constraints of Upper Ordovician Gondwanan faunas. As currently known, the Fombuena Formation has produced six named taxa (four diplobathrid camerates, one monobathrid camerate, and one cladid) and two camerate taxa left in open nomenclature, making it the most diverse Katian age crinoid fauna identified from Gondwana. Most well-sampled Laurentian faunas are dominated by cladids, disparids, or both cladids and disparids. By contrast, the assemblage from the Fombuena Formation is predominantly comprised of camerates; cladids are represented by one taxon and disparids are unknown. This suggests that Katian crinoid faunas of Gondwana may have had a notably different composition and diversification history than those of Laurentia in terms of clade composition. However, improved sampling of the Katian of Gondwana is necessary to further validate this hypothesis.

The crinoids recovered from the Fombuena Formation represent an unexpectedly diverse fauna. The rocks of this formation represent siliciclastic sedimentation in a cool-water environment during the beginning of the Late Ordovician in high-latitude Gondwana. On the basis of the scarcity of crinoid taxa identified from the Middle and Upper Ordovician of Gondwana, these conditions have been cited as factors that potentially limited the diversification of Ordovician Gondwanan crinoid faunas (Lefebvre et al., 2013). Recovery of diverse crinoid material from the Fombuena Formation, however, indicates these factors did not prevent diversification of crinoids in these environments, particularly with respect to camerate crinoids. The diversity of camerate crinoids is particularly notable given the siliciclastic composition of the formation. Camerate crinoids are typically considered to have preferred carbonate environments, a condition inferred to relate to both strategies for substrate attachment and feeding ecology (Ausich, 1985; Kammer and Ausich, 2006), although most studies of preference for carbonate versus siliciclastic environments have focused on Mississippian crinoids. Thus, it does not appear that the Katian camerates of Gondwana had the same environmental limitations as camerate crinoids from later intervals.

The crinoid fauna from the Fombuena Formation appears to represent the beginning of the transition from highly endemic Middle Ordovician faunas to more cosmopolitan Late Ordovician faunas (Lefebvre et al., 2013), which is related to the first pulses of the warming Boda event in Gondwana (Fortey and Cocks, 2005; Zamora et al., 2014). The monobathrid camerate Eopatelliocrinus, which was previously known only from Laurentia, is now recognized as a more cosmopolitan genus based on the description of E. hispaniensis, n. sp. Although endemic, three of the four diplobathrid camerates belong to the family Anthracocrinidae, which was previously known from only a few Laurentian specimens. Ausich and Deline (2012) concluded that the more cosmopolitan Silurian faunas had their phylogenetic roots in Ordovician lineages from North America, and it appears that the Fombuena Formation crinoids may also be closely linked with Laurentian faunas. The cladid Picassocrinus n. gen. n. sp., however, has a unique morphology among Ordovician crinoids and represents a genus that is currently unknown outside Gondwana. Whereas Katian faunas in Laurentia had already begun to transition to the composition of middle Paleozoic CEFs (i.e., more cladids and monobathrid camerates and fewer diplobathrid camerates), the Fombuena fauna is still very much dominated by diplobathrid camerate crinoids. This suggests the transition from the early to the middle Paleozoic CEF was asynchronous across the globe.

\section{Systematic paleontology}

The suprageneric classification used here is from Moore \& Teichert (1978) and Ausich (1998a, 1998b). Morphological terminology follows Ubaghs (1978). The plating in the interrays is given as the number of plates in each range from the proximalmost plate to the last range before the tegmen. In the posterior 
Table 1. Clade composition of Katian faunas at the generic level (excluding columnal taxonomy). Data taken largely from Webster and Webster (2014) and from the database of Peters and Ausich (2008).

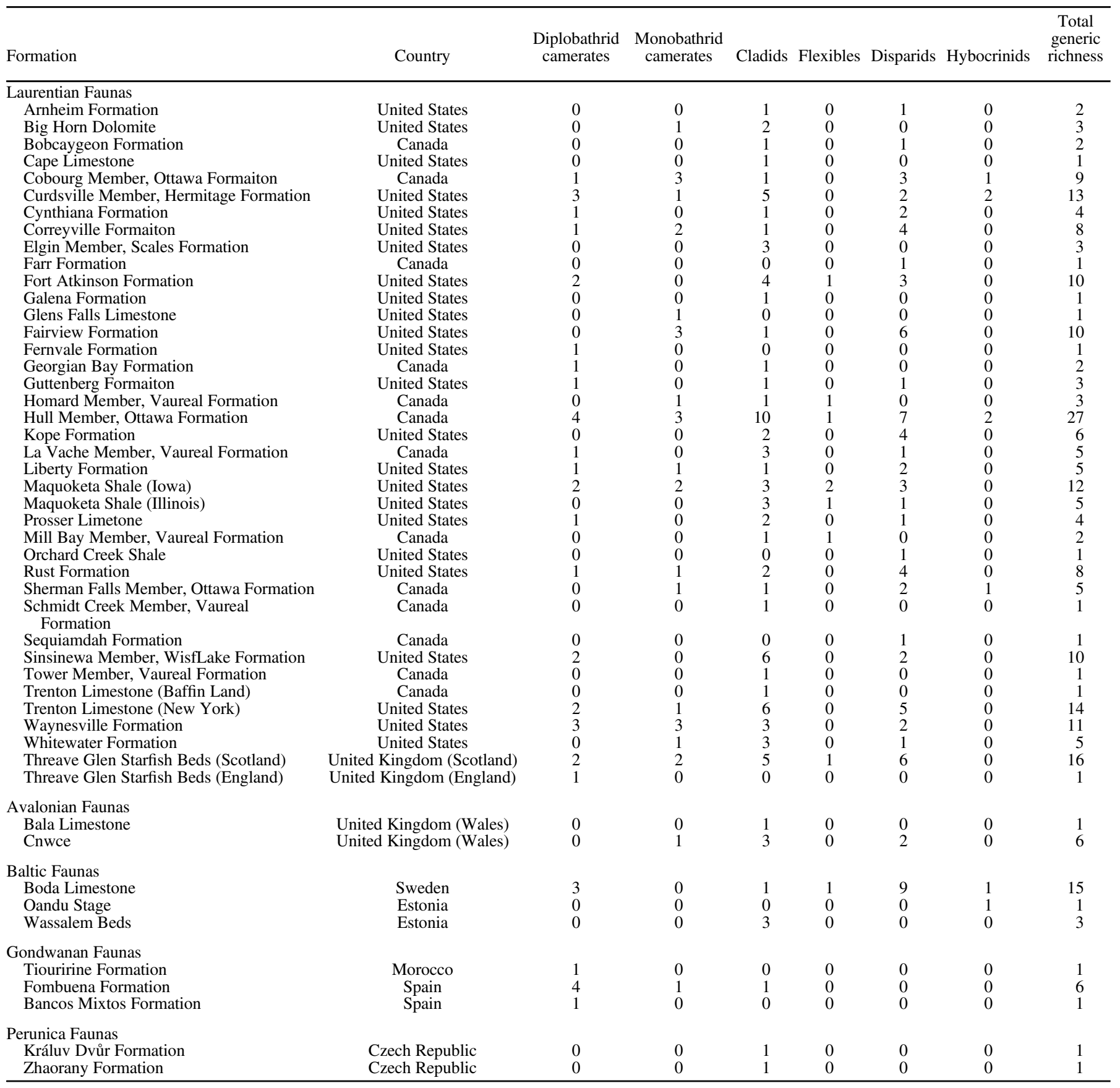

interray, the primanal is indicated by "P" and the first interradial in regular interrays is indicated by "1." A "?" given in the interray series indicates more distal plating is unknown.

In the measurement sections and the table of measurements (Table 2), asterisks indicate measurements that are of compressed or incomplete specimens; two asterisks indicates holotype specimens. All measurements are in millimeters unless otherwise noted.

Class Crinoidea Miller, 1821

Subclass Camerata Wachsmuth and Springer, 1885 Order Diplobathrida Moore and Laudon, 1943

Family Anthracocrinidae Strimple and Watkins, 1955
Emended diagnosis.-Dicyclic camerate with basal concavity involving infrabasals and partial basals; median ray ridges faint to prominent; fixed brachials bifurcating twice within the calyx; regular interray plating $1-2$ or $1-3$, either with the first interray plate enlarged or plating forming a weak to prominent biseries; posterior interray differentiated or undifferentiated; fixed secundibrachials and tertibrachials; free arm openings 15 or 20 ; lower pinnules enlarged, typically fixed.

Remarks.-Assignment of new taxa to Anthracocrinidae broadens both the morphological concept and geographic range of this family. Two characters previously considered diagnostic of 
Table 2. Measurements for diplobathrid crinoid specimens. All measurements are in millimeters. Asterisk $(*)$ indicates measurement of compressed or incomplete specimen; double asterisk (**) indicates holotype specimen; question mark (?) indicates feature not measured due to nonpreservation.

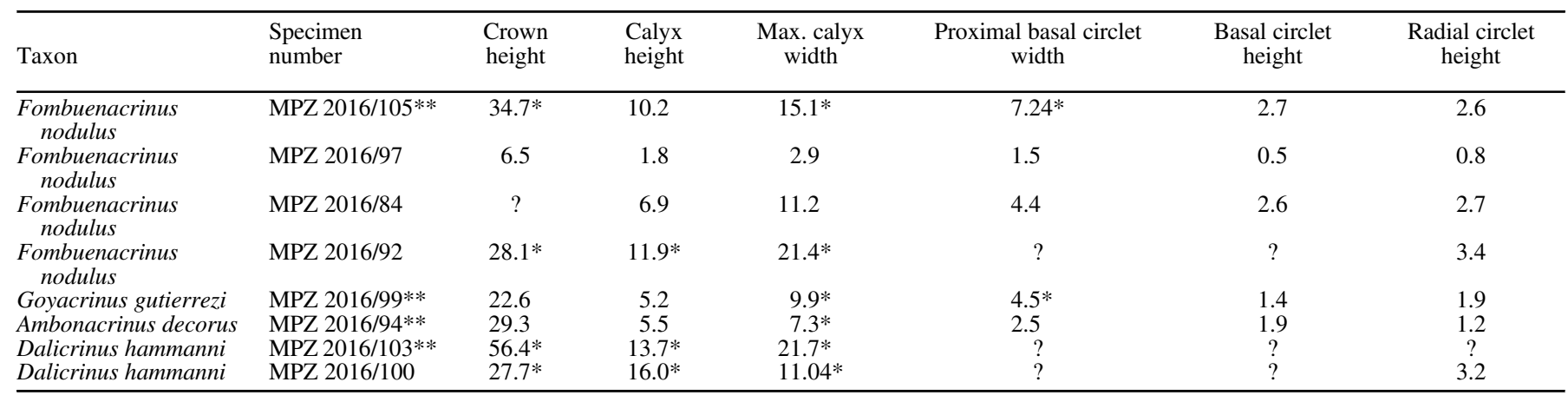

Anthracocrinidae (fixed pinnules and lack of anitaxial plating in the posterior interray) are no longer invariable in all genera assigned to the family. In particular, Goyacrinus gutierrezi n. gen. n. sp. possesses an anitaxial ridge in the posterior interray and lacks fixed pinnules, and Fombuenacrinus nodulus n. gen. n. sp. variably possesses fixed pinnules. Although these two new taxa differ in their possession of these characters, they are still unambiguously united with other genera assigned to Anthracocrinidae on the basis of the characters given in the preceding emended diagnosis. Because these traits represent a unique suite of characters among Ordovician diplobathrids, emending the diagnosis of Anthracocrinidae has been deemed a more conservative approach than erecting a new family to hold these genera.

The genera previously assigned to Anthracocrinidae are known only from the Ordovician of Laurentia. Thus, the addition of three new genera extends the known geographic range of Anthracocrinidae to Gondwana.

\section{Genus Fombuenacrinus new genus}

Type species.-Fombuenacrinus nodulus new species, by monotypy.

Diagnosis.-As for species, by monotypy.

Etymology.-Fombuenacrinus is derived from the village of Fombuena, which is near the site of collection.

Remarks.-Fombuenacrinus is assigned to the Anthracocrinidae on the basis of confinement of the infrabasals and proximal basals to the basal concavity, radials separated by a large first interray plate, fixed brachials bifurcating twice within the calyx giving rise to secundibrachials and tertibrachials, 20 free arm openings, lower pinnules enlarged and variably fixed, and undifferentiated posterior interray.

Fombuenacrinus differs from most Anthracocrinidae in that only the lowest pinnule is variably fixed. All other genera previously assigned to Anthracocrinidae possess numerous fixed pinnules in rays, half rays, and often quarter rays. Fombuenacrinus is most similar to Anthracocrinus Strimple and Watkins, 1955 but is differentiated by a globose to bowl-shaped calyx, highly convex median ray ridges, interrays in contact with the tegmen, few fixed pinnules, 20 free arms, and biserial brachials. By contrast, Anthracocrinus has a conical to subconical calyx, broad and low median ray ridges, fixed pinnules that prevent contact of interrays with the tegmen, 15 free arms, and uniserial brachials. Fombuenacrinus also shares many similarities with Visocrinus Ausich et al., 2002 from the Katian of Spain. Visocrinus is currently assigned to Rhodocrinitidae but possesses most diagnostic features of Anthracocrinidae. Thus, family reassignment may be in order for this genus but is beyond the scope of this study. Fombuenacrinus is differentiated from Visocrinus by its undifferentiated posterior interray, large first interradial plate, and brachials fixed to the third tertibrachial. By contrast, Visocrinus has a differentiated posterior interray, small first interradial plate, and brachials fixed to the fourth tertibrachial.

Fombuenacrinus nodulus new species

Figures 3.1, 3.2, 3.7, 3.8, 3.11, 3.12, 4.1, 4.2

2015a camerate crinoid in Zamora et al., p. 237, figs. 19K, 19L

Type material.-The holotype (MPZ2016/105) and four paratypes (MPZ2016/84, 85, 92 [part and counterpart], 97).

Diagnosis._Anthracocrinid with globose to bowl-shaped calyx; highly convex median ray ridges; infrabasals confined to basal concavity; first interray plate very large; all interrays contiguous with the tegmen; proximal interray plating 1-2?; CD interray not differentiated from other rays; four arms per ray; fixed secundibrachials and tertibrachials; intrabrachial plates between fixed secundibrachials and tertibrachials of adjacent half rays and between fixed tertibrachials of adjacent quarter rays; free arms unbranched; first pinnule variably fixed; first two pinnules enlarged; mature brachials wedge biserial.

Occurrence.-Fombuena Formation, Huerva Member, upper middle Berounian (lower Katian, Upper Ordovician), near Fombuena (Zaragoza province), Spain; Localities 1 and 2.

Description.-Calyx globose to bowl shaped, wider than high; plates with fine stellate ornamentation; plate sutures indistinct, flush with plate surface; shallow basal concavity surrounded by continuous pentagonal rim; ray ridges distinct, bulbous, widest at plate sutures, ornamented with parallel ridges; basals and radials ornamented with heavy ridges forming a pentastellate pattern at base of calyx. 


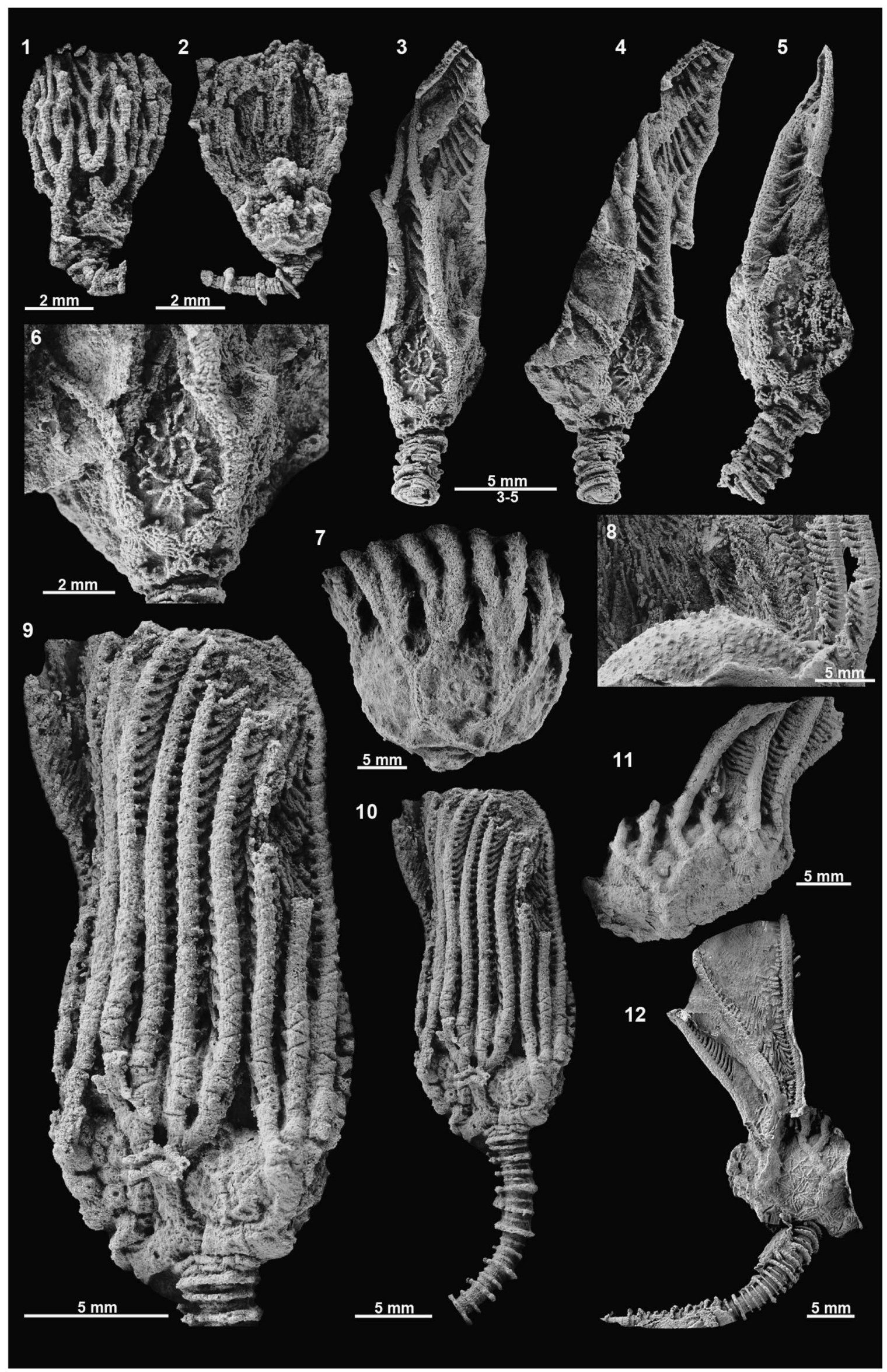


Infrabasal plates likely five, completely hidden in basal concavity. Basal circlet forming rim of basal concavity, visible in side view; basal plates five, quadrangular, tapering distally, slightly higher than wide.

Radial circlet interrupted in all rays; radial plates five, pentagonal, wider than high, similar in size to basals.

Interrays wide, all of equal width, in contact with tegmen, not depressed, interrupting the radial circlet in all rays; no apparent differentiation of CD interray. First interradial plate approximately as wide as high, comprising most of the interray to at least the height of the first secundibrachial. Second range likely constructed of two plates, plating of higher rows unknown.

First primibrachial fixed, rectangular, wider than high; second primibrachial axillary, hexagonal. Secundibrachials two, fixed, second axillary; distal-most fixed brachial second or third tertibrachial. Intrabrachial plates between secundibrachials and tertibrachials of adjacent half rays and between tertibrachials of adjacent quarter rays.

Arm openings 20, ungrouped (Fig. 3.11, 3.12) or grouped by half rays in pairs of two (Fig. 3.8); free arms unbranched. Brachials proximally cuneate uniserial transitioning to flat chisel biserial in mature arms. Pinnules thin, elongate; first two pinnules enlarged, usually on third and fifth tertibrachial of each arm, lowermost pinnule sometimes fixed, pinnules on every brachial distally.

Tegmen low, convex, comprised of numerous small plates; plates undifferentiated, ornamented with elongated nodes. Position and nature of anal opening unknown.

Proximal stem circular, heteromorphic; holomeric in adult specimens (Fig. 3.7, 3.11, 3.12), pentameric in juveniles (Fig. 3.1, 3.2), N3231323. Lumen, distal stem, and holdfast unknown.

Etymology.-Nodulus, after the Latin for swelling or knot, in reference to the swelling of the median ray ridges at plate sutures.

Measurements.-Holotype and paratype measurements are given in Table 2.

Remarks.-Specimen MPZ 2016/97, part and counterpart (Fig. 3.1, 3.2), represents a juvenile form of Fombuenacrinus nodulus. The cup is approximately $2 \mathrm{~mm}$ high, in contrast with the adult specimen MPZ 2016/105 (Fig. 3.12), which is approximately $10 \mathrm{~mm}$ high (Table 2). The juvenile specimen retains a number of features characteristic of adults of the species, including heavy ridges ornamenting the basals and radials (Kolata, 1982), stellate ornamentation on the interradial plates, two primibrachials, two secundibrachials, and enlargement of the first two pinnules. Fewer brachial and interradial plates are fixed in the juvenile form, indicating interray plates grew to incorporate the brachials through ontogeny, and brachials are free above the first or second primibrachial. In the free arms of the juvenile specimen, brachials are rectangular and more than twice as high as wide. Enlarged pinnules give the false impression of asymmetric branching (Fig. 3.1). The first two pinnules on the second and fourth brachials are enlarged; distally, pinnules are smaller and are on every brachial. The juvenile stem is pentameric and not fully differentiated to the adult heteromorphic condition; all columnals are equal in circumference and thickness with the exception of the primary nodals, which are enlarged. This indicates the stem internodals differentiated later in ontogeny and the stem meres later fused to become holomeric in at least the proximal stem.

\section{Genus Goyacrinus new genus}

Type species.-Goyacrinus gutierrezi new species, by monotypy.

Diagnosis.—As for species, by monotypy.

Etymology.-Goyacrinus, in recognition of the Spanish painter, Francisco José de Goya y Lucientes, who was born in Fuendetodos (Zaragoza province), several kilometers north of the locality were this crinoid was collected.

Remarks.-Goyacrinus is assigned to the Anthracocrinidae on the basis of its basal concavity including infrabasals and partial basals, median ray ridges, regular interray plating in biseries, fixed tertibrachials, enlarged first pinnules, and 20 free arm openings. Goyacrinus is the only genus assigned to Anthracocrinidae known to possess an anal series and anitaxial ridge, and it also lacks the fixed pinnules characteristic of most anthracocrinids.

Goyacrinus is similar to Anthracocrinus on the basis of biserial plating in the regular interrays, fixed intrabrachials only present medially between adjacent half rays (not quarter rays), differentiation of the posterior interray, arms that become free above the first or second tertibrachial, and unbranched free arms. Goyacrinus is distinguished from Anthracocrinus by its prominent median ray ridges, anal series in the posterior interray, regular interrays in contact with the tegmen, regular interrays with prominent biserial plating, 20 free arms, cuneate biserial brachials in mature arms, and no fixed pinnules. Anthracocrinus possesses low and broad median ray ridges, no anal series in the posterior interray, regular interrays that are not in contact with the tegmen, regular interrays with weak biserial plating, 15 free arms, cuneate uniserial brachials in mature arms, and fixed pinnules. Goyacrinus is also morphologically similar to Cotylacrinna Brower, 1994, which is currently assigned to Rhodocrinitidae. Because Cotylacrinna

\footnotetext{
Figure 3. Camerate crinoids from the Fombuena Formation of Spain. $(\mathbf{1}, \mathbf{2}, \mathbf{7}, \mathbf{8 , 1 1 , 1 2})$ Fombuenacrinus nodulus $\mathrm{n}$. gen. n. sp.: $(\mathbf{1}, \mathbf{2})$ lateral views of juvenile crown, part and counterpart, paratype, MPZ 2016/97; (7) lateral view of calyx and proximal arms, paratype, MPZ2016/84; (8) tegmen and proximal arms, paratype, MPZ2016/85; (11) lateral view of partial calyx and proximal arms, paratype, MPZ2016/92; (12) lateral view of crown, holotype, MPZ2016/105; (3-6) Ambonacrinus decorus n. gen. n. sp., holotype, MPZ2016/94; (3) DE-interray view of calyx and proximal arms; (4) E-ray view of calyx and proximal arms; (5) CD-interray view of calyx and proximal arms, note anitaxial ridge originating from C radial; (6) DE-interray view of calyx; (9, 10) Goyacrinus gutierrezi n. gen. n. sp., holotype, MPZ2016/99; (9) lateral view of crown; (10) lateral view of crown and proximal stem.
} 


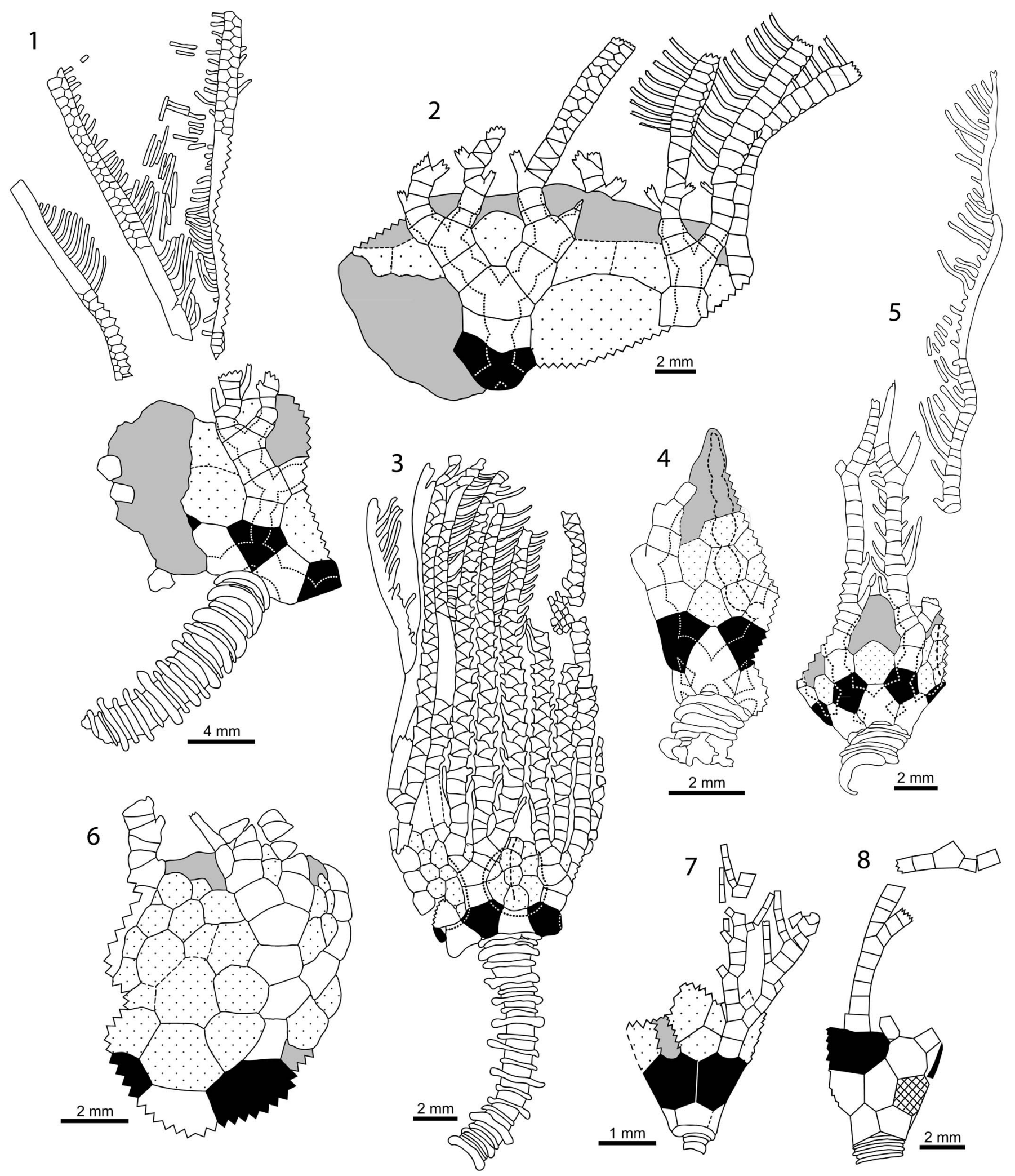

Figure 4. Camera lucida drawings of described taxa. (1, 2) Fombuenacrinus nodulus: (1) holotype, MPZ2016/105; (2) paratype, MPZ2016/92; (3) Goyacrinus gutierrezi, holotype, MPZ2016/99; (4, 5) Ambonacrinus decorus, holotype, MPZ2016/94; (6) Dalicrinus hammanni, paratype, MPZ2016/100; (7) Eopatelliocrinus hispaniensis, holotype, MPZ2016/81; (8) Picassocrinus villasi, holotype, MPZ2016/83. Grey shading = matrix/ambiguous plating; dotted lines $=$ ray ridges; dashed lines $=$ inferred plate boundaries; heavy dashed lines $=$ anitaxial ridge; stippled $=$ interray plates; black $=$ radial plates; diagonal ruling $=$ anal plates; zig-zag lines $=$ broken edges. 
possesses all the diagnostic features of Anthracocrinidae, family reassignment of the genus may be in order, but this is beyond the scope of this study. Morphological characters shared by Goyacrinus and Cotylacrinna include grouping of the arms, differentiation of the posterior interray, presence of an anal series and ridge, and unbranched arms. Goyacrinus differs from Cotylacrinna on the basis of its low bowl-shaped calyx, no lobation of the calyx at the arm bases, heavy median ray ridges, two secundibrachials, fixed intrabrachial plates between secundibrachials of adjacent half rays, no fixed pinnules, and wedge biserial brachials in mature arms. By contrast, Cotylacrinna has a globose calyx, lobate arm bases, weak median ray ridges, four secundibrachials, no intrabrachial plates, fixed pinnules, and flat chisel biserial brachials in mature arms.

\section{Goyacrinus gutierrezi new species} Figures 3.9, 3.10, 4.3

Holotype.-The holotype, MPZ2016/99, is the only known specimen of this species.

Diagnosis.-Anthracocrinid with low bowl-shaped calyx; prominent median ray ridges; infrabasals confined to basal concavity; regular interray plating in biseries; P-3 plating in proximal $\mathrm{CD}$ interray; anitaxis plating with anitaxial ridge; 20 free arms; arms unbranched; brachials cuneate biserial.

Occurrence.-Fombuena Formation, Huerva Member, upper middle Berounian (lower Katian, Upper Ordovician), near Fombuena (Zaragoza province), Spain; Locality 1.

Description.-Calyx low bowl shaped, wider than high; plates ornamented with thick, irregular stellate ridges; plate sutures flush with plate surface; median ray ridges heavy; basal concavity lacking any surrounding rim.

Infrabasal plates likely five, completely hidden in basal concavity. Basal circlet forming rim of basal concavity, partially visible in side view; basal plates five, quadrangular, tapering distally, wider than high.

Radial circlet interrupted in all rays; radial plates five, pentagonal, wider than high, slightly larger than basals, largest plates in calyx.

Regular interrays in contact with tegmen, not depressed, interrupting the radial circlet in all rays. First row of interradial plates only partially visible, likely one plate in first row; four higher rows with two plates each, forming a biseries.

CD interray wider than other interrays, in contact with tegmen; primanal small, septagonal, approximately as high as wide; second row with three plates; proximal plating 1-3-3-3; faint anitaxial ridge along medial column of plates.

First primibrachial fixed, rectangular, wider than high; second primibrachial axillary, pentagonal. Secundibrachials two, fixed, second axillary; distal-most fixed brachial first tertibrachial. Single intrabrachial plate between secundibrachials in adjacent half rays.

Arm openings 20, grouped in each ray; free arms unbranched. Brachials proximally rectilinear uniserial transitioning to wedge biserial in mature arms. Pinnules on every free brachial, beginning on the second tertibrachial, first pinnule enlarged.

Tegmen unknown. Position and nature of anal opening unknown.

Proximal stem circular, heteromorphic, holomeric, N3231323; lumen, distal stem, and holdfast unknown.

Etymology.-Gutierrezi, in recognition of Juan Carlos Gutiérrez-Marco, who has greatly contributed to understanding of the Ordovician of the Iberian Chains and did pioneering work on echinoderms from the Fombuena Formation (GutiérrezMarco et al., 1996).

Measurements.-Holotype measurements are given in Table 2. Genus Dalicrinus new genus

Type species.—Dalicrinus hammanni new species, by monotypy.

Diagnosis.—As for the species, by monotypy.

Etymology.-Dalicrinus, in recognition of the Spanish surrealist painter, Salvador Dalí, with reference to the irregular plating of the interradial areas.

Remarks.-Dalicrinus is assigned to the Anthracocrinidae on the basis of its basal concavity including infrabasals and partial basals, prominent median ray ridges, fixed brachials bifurcating twice within the calyx, 20 free arm openings, and fixed pinnules. Dalicrinus differs from most anthracocrinids in that the interrays are composed of numerous $(>20)$, irregular plates that vary in both size and organization within interrays. Other anthracocrinid genera typically have interrays made up of fewer $(\leq 10)$ regularly organized plates.

Of taxa currently assigned to Anthracocrinidae, Dalicrinus is most similar to Gustabilicrinus Guensburg, 1984 as both taxa have medium bowl-shaped calyces, infrabasals confined to the basal concavity, intrabrachials between fixed brachials of adjacent half rays and quarter rays, and fixed pinnules on the lateral margins of half rays. Dalicrinus differs from Gustabilicrinus in its prominent ray ridges, numerous interradial plates with irregular plating, and grouped, biserial arms. By contrast, Gustabilicrinus lacks distinct ray ridges, has few $(<10)$ interray plates with regular plating, and has ungrouped, uniserial arms. Dalicrinus also shares many morphological similarities with Rheocrinus Haugh, 1979. Both taxa have bowl-shaped aboral cups, infrabasals restricted to the basal concavity, fixed pinnules, and biserial arms. In addition, the interray plating of Rheocrinus is irregular in distal ranges, but interray plates are not as variable in size or organization as those of Dalicrinus. Dalicrinus primarily differs from Rheocrinus in its distinct ray ridges, large number of interradial plates $(>20)$, and the presence of intrabrachial plates between adjacent half rays and quarter rays. By contrast, Rheocrinus has faint ray ridges, interrays with few $(<10)$ interradial plates, and no intrabrachial plates. 
Dalicrinus hammanni new species

Figures 4.6, 5.1-5.6

Type material.-The holotype (MPZ2016/94) and two paratypes (MPZ2016/90, 100).

Diagnosis.-Anthracocrinid with medium bowl-shaped calyx; prominent median ray ridges; infrabasals confined to basal concavity; regular interrays with numerous $(>20)$ plates, plating 1-3 proximally, irregular in higher ranges; fixed intrabrachial plates between fixed secundibrachials and tertibrachials of adjacent half rays and between fixed tertibrachials of adjacent quarter rays; fixed pinnules on lateral margins of fixed rays; 20 free arms; arms grouped by half rays; arms unbranched; brachials wedge chisel biserial.

Occurrence.-Fombuena Formation, Huerva Member, upper middle Berounian (lower Katian, Upper Ordovician), near Fombuena (Zaragoza province), Spain; Localities 1 and 2.

Description.-Calyx medium bowl shaped, slightly higher than wide; circlet plates, lower fixed brachials, and lower interradial plates ornamented with stellate ridges; intrabrachial and higher interradial plates bulbous, ornamented with irregular ridges; plate sutures flush with plate surface on fixed brachials, depressed between interradial plates; ray ridges prominent.

Infrabasal plates five, wider than high, confined to the basal concavity. Basal circlet forming rim of basal concavity, visible in side view; basal plates five, hexagonal, tapered distally, wider than high, proximally flared to form the rim of the basal concavity.

Radial circlet interrupted in all rays; radial plates five, pentagonal, wider than high. Regular interrays wide, in contact with tegmen, not depressed, interrupting the radial circlet in all rays. First interradial plate large, hexagonal, wider than high; second range with three plates, followed by 5 ? plates in the second row; higher rows with variable plating pattern and plate size; at least 20 plates total per interray in at least seven rows.

Posterior interray not observed or undifferentiated.

First primibrachial fixed, rectangular, wider than high; second primibrachial axillary, pentagonal. Secundibrachials two, second secundibrachial axillary; three fixed tertibrachials incorporated into calyx. Fixed intrabrachial plates between fixed secundibrachials and tertibrachials of adjacent half rays, proximal plating 1-2-2-2-2; fixed intrabrachial plates between fixed tertibrachials of adjacent quarter rays, forming a single column of three plates that decrease in size distally. Fixed pinnules on lateral sides of each half ray.

Arm openings 20, free above the third tertibrachial, grouped within each half ray; free arms unbranched as known. Brachials cuneate uniserial proximally, wedge chisel biserial distally. Pinnules on every free brachial.
Tegmen, anal opening, stem, and holdfast unknown.

Etymology.-Hammanni, in recognition of Wolfgang Hammann, who contributed much to the study of Ordovician stratigraphy of the Iberian Chains.

Measurements.-Holotype and paratype measurements are given in Table 2.

Family Rhodocrinitidae Roemer, 1855

Genus Ambonacrinus new genus

Type species.-Ambonacrinus decorus new species, by monotypy.

Diagnosis.—As for species, by monotypy.

Etymology.-Ambonacrinus, after the Greek ambon for ridge or crest, in reference to the prominent anitaxial ridge in the posterior interray.

Remarks.-Ambonacrinus decorus is known from a single specimen. Because the plates are very tightly sutured and minimal disarticulation has occurred, it is difficult to determine plating of the regular interrays beyond the first interradial plate. Despite this uncertainty of plating in the regular interrays, Ambonacrinus can be assigned to the Rhodocrinitidae because of the presence of radials separated in all interrays and 10 free arm openings. It is most closely allied with the Group II rhodocrinitids (Ausich, 1986) on the basis of its prominent median ray ridges, uniserial arms, and medium bowl-shaped calyx.

The condition in Ambonacrinus of an anal series originating from the $\mathrm{C}$-ray primibrachial is unusual in camerate crinoids (Gahn, 2015) and clearly designates Ambonacrinus as a new genus. Other genera described with this condition are Cefnocrinus Botting, 2003 and Pararchaeocrinus Strimple and Watkins, 1955. Cefnocrinus has a medium globose calyx, basals that are wider than high, two rows of plates between the anal series and D ray, arms that become free above the fourth or fifth secundibrachial, fixed pinnules, cuneate biserial arms, and free arms that branch twice isotomously; Pararchaeocrinus has a medium globose calyx, basals that are wider than high, proximally one row and distally two rows of plates between the anal series and D ray, arms that become free above the fourth secundibrachial, no fixed pinnules, cuneate uniserial to cuneate biserial arms, and free arms that are poorly isotomously branched at least three times; and Ambonacrinus has a subconical calyx, basals that are as high as wide, one row of plates between the anal series and D ray, arms that become free above the second or third secundibrachial, no fixed pinnules, rectilinear uniserial to weakly cuneate uniserial arms, and free arms that branch once isotomously.

Figure 5. Crinoids from the Fombuena Formation of Spain. (1-6) Dalicrinus hammanni $\mathrm{n}$. gen. $\mathrm{n}$. sp.: (1) lateral view of partial crown with incomplete arms, holotype, MPZ2016/103; (2) lateral view of calyx and partial arms, paratype, MPZ2016/100; (3) lateral view of calyx and partial arms, paratype, MPZ2016/100; (4) basal view, paratype, MPZ2016/100; (5) lateral view of distal portion of calyx, paratype, MPZ2016/90; (6) internal view of partial calyx, paratype, MPZ2016/ 90; (7) Eopatelliocrinus hispaniensis n. sp., lateral view of crown and partial stem, holotype, MPZ2016/81; (8-10) Picassocrinus villasi n. gen. n. sp., part and counterpart, holotype, MPZ2016/83; (8) CD-interray view of calyx with partial arms; (9) CD-interray view of calyx with partial arms and stem; (10) lateral view of calyx with partial arms and stem. 


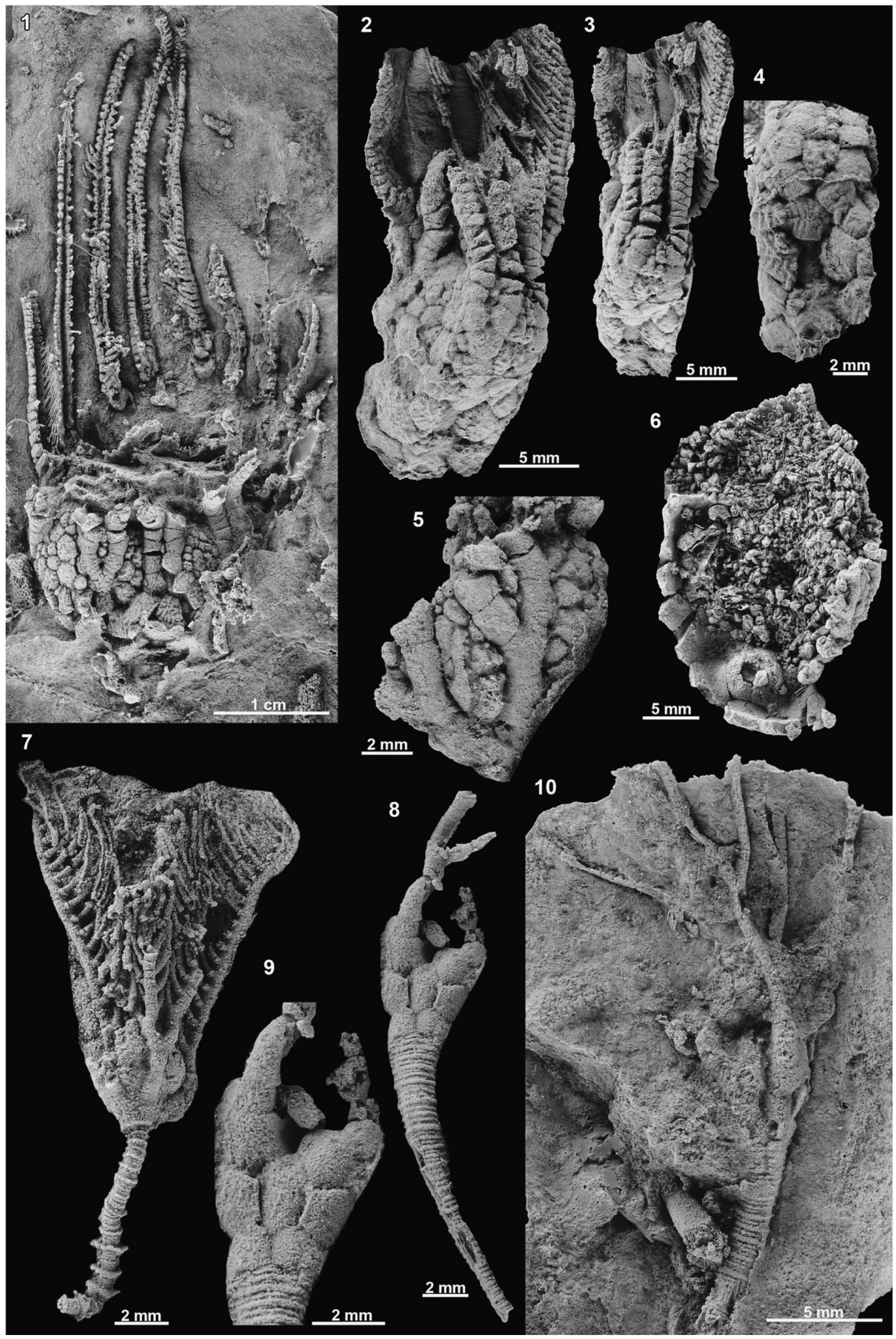


Although the posterior plating of Ambonacrinus is similar to that of Cefnocrinus and Pararchaeocrinus, it is most morphologically similar to Rhaphanocrinus Wachsmuth and Springer, 1885 on the basis of its strong median ray ridges, hidden infrabasals, fixed secundibrachials and intersecundibrachials, anal series in the posterior interray, and ten uniserial arms. Ambonacrinus is differentiated from Rhaphanocrinus by its subconical calyx, contact of the primanal with the C-ray primibrachial, and origin of the anal series and anitaxial ridge from the C-ray primibrachial. By contrast, Rhaphanocrinus has a calyx shape that ranges from bowl shaped to globose, primanal located above the CD basal, and anal series that originates from the center of the interray.

\section{Ambonacrinus decorus new species}

Figures 3.3-3.6, 4.4, 4.5

Holotype.-The holotype, MPZ2016/94, is the only known specimen of this species.

Diagnosis.-Rhodocrinitid with medium conical calyx; infrabasals hidden; median ray ridges; all interrays in contact with tegmen; CD interray wider, anal series with anitaxial ridge originating from $\mathrm{C}$-ray primibrachial; fixed primibrachials and secundibrachials; intrabrachial plates between fixed secundibrachials; 10 free arms, branched isotomously; brachials rectilinear uniserial.

Occurrence.-Fombuena Formation, Huerva Member, upper middle Berounian (lower Katian, Upper Ordovician), near Fombuena (Zaragoza province), Spain; Locality 2.

Description.-Calyx medium conical, wider than high; plates with heavy stellate ornamentation; plate sutures indistinct, flush with plate surface; ray ridges prominent, bulbous, ornamented with irregular parallel ridges, widest at plate sutures; calyx base surrounded by stellate rim.

Infrabasal plates likely five, completely hidden by stem. Basal circlet forming rim of basal concavity, visible in side view, proximal margin covered by stem; basal plates five, largest plates in calyx, hexagonal, truncated distally, as high as wide.

Radial circlet interrupted in all rays; radial plates five, pentagonal, wider than high. Regular interrays in contact with tegmen, slightly depressed, interrupting the radial circlet in all rays. First interradial plate septagonal, as wide as high. Higher ranges of plates undefined.

Posterior interray wider, in contact with tegmen. First plate in the center of CD interray not clearly differentiated as primanal. First well-defined anal plate in contact with C-ray first primibrachial and upper left margin of $\mathrm{C}$ radial; anal series originating from C-ray first primibrachial, comprised of a column of hexagonal plates with prominent anitaxial ridge. Proximal plating 1-3-3-3?, higher ranges of plates unknown.

First primibrachial fixed, hexagonal, wider than high; second primibrachial axillary, pentagonal. Secundibrachials free above second or third secundibrachial. Intrabrachial plates between each adjacent half ray; plating pattern unknown.

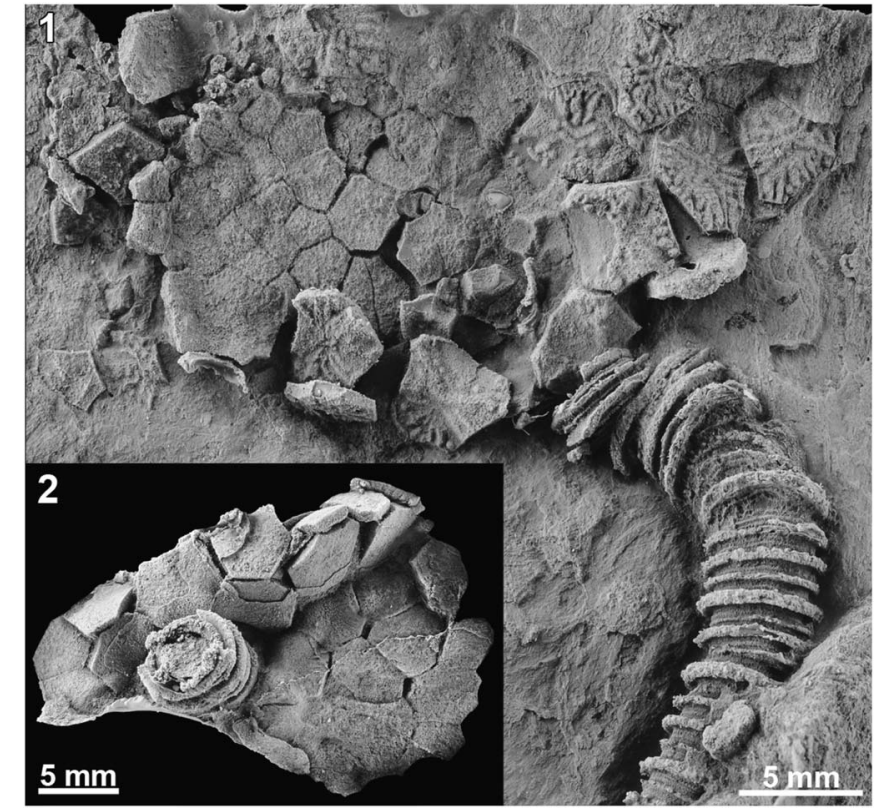

Figure 6. Unidentified camerates from the Fombuena Formation of Spain (1) Diplobathrida gen. indet. sp. indet., internal view of disarticulated calyx and proximal stem, MPZ2016/104; (2) Camerata gen. indet. sp. indet., basal view of partial calyx and proximal stem, MPZ2016/93.

Arm openings 10, ungrouped; free arms branching once isotomously. Brachials rectilinear uniserial proximally, weakly cuneate uniserial distally. Pinnules on every free brachial; D ray pinnule enlarged on side of CD interray ray.

Tegmen and anal opening unknown.

Proximal stem circular, heteromorphic, holomeric. Lumen, internoditaxis sequence, distal stem, and holdfast unknown.

Etymology.-Decorus, after the Latin for ornamented or decorated, in reference to the elegant ornamentation of the calyx.

Measurements.-Holotype measurements are given in Table 2.

Diplobathrida genus indeterminate species indeterminate Figure 6.1

Remarks.-This species is represented by one specimen that consists of a crushed partial calyx and proximal stem. The specimen preserves incomplete proximal circlets, an interior portion of the theca, and some surrounding disarticulated plates. Infrabasal plates are as wide as high with an imprint of the circular stem cicatrix. Basal plates are hexagonal, wider than high, ornamented with stellate ridges, and proximally flared to form the rim of a basal concavity. The stem is circular and heteromorphic with noditaxis sequence N3231323.

The presence of an infrabasal circlet and interradial plates indicates this specimen belongs to Diplobathrida. Ornamentation of the calyx plates and arrangement of stem nodals and internodals are similar to those of Goyacrinus gutierrezi, and this specimen may belong to that species. Because other circlets and interrays are indistinguishable, however, it is not possible to confidently identify this specimen beyond the level of order. 
Material.-The taxon is known from a single specimen, MPZ2016/104.

Occurrence.-Fombuena Formation, Huerva Member, upper middle Berounian (lower Katian, Upper Ordovician), near Fombuena (Zaragoza province), Spain; Locality 2.

Camerata genus indeterminate species indeterminate Figure 6.2

Remarks.-This taxon is represented by a single partial calyx. The specimen consists of the proximal portion of a crushed calyx with proximal stem attached. Calyx plates are large, all of approximately similar size, flat to slightly convex, lacking median ray ridges or ornamentation. The stem is circular, heteromorphic, with a large circular lumen. One partial interray with plating 1-3-?; the first interradial plate hexagonal, distally tapered, separating adjoining radials.

The lack of any plate ornamentation and the relative sizes of the calyx plates indicate this specimen represents a distinct species from this fauna. The poor preservation and degree of disarticulation of the specimen prevents confident identification of other circlet plates and precludes assignment beyond that of subclass.

Material.-The taxon is known from a single specimen, MPZ2016/93.

Occurrence.-Fombuena Formation, Huerva Member, upper middle Berounian (lower Katian, Upper Ordovician), near Fombuena (Zaragoza province), Spain; Locality 2.

Order Monobathrida Moore and Laudon, 1943

Suborder Glyptocrinina Moore, 1952

Superfamily Patelliocrinoidea Angelin, 1878

Family Patelliocrinidae Angelin, 1878

Genus Eopatelliocrinus Brower, 1973

Type species.—Eopatelliocrinus scyphogracilis Brower, 1973; by original designation.

Other species.-E. latibrachiatus Brower, 1973; E. ornatus (Billings, 1857); E. hispaniensis n. sp.

Occurrence.-Previously, Eopatelliocrinus was known exclusively from the Katian of North America (Brower, 1973, 1994). The occurrence of E. hispaniensis in the Katian of Spain expands its known range to Laurentia and Gondwana.

Remarks.-The occurrence of Eopatelliocrinus in Spain represents only the third crinoid genus to occur in both Gondwana and Laurentia during the Ordovician (Zamora et al., 2015b). The two other examples are the disparid Iocrinus Hall, 1866 and the presumed cladid Merocrinus Walcott, 1883. These two genera are relatively long ranging and known from numerous localities, which makes the appearance of Eopatelliocrinus in Gondwana somewhat unexpected and highlights the utility of improved sampling from underrepresented paleogeographic regions.
Eopatelliocrinus hispaniensis new species

Figures 4.7, 5.7

2015a camerate crinoid Zamora et al., p. 237, fig. 19F.

Holotype.-The holotype, MPZ2016/81, is the only known specimen of this species.

Diagnosis.—Calyx relatively small, medium cone shaped; basal rim present; smooth plate sculpturing, no depression at calyx plate boundaries; ray ridges extend onto fixed brachials; arms robust, taper gently; proximal column circular.

Occurrence.-Fombuena Formation, Huerva Member, upper middle Berounian (lower Katian, Upper Ordovician), near Fombuena (Zaragoza province), Spain; Locality 2.

Description.-Calyx large in size; medium vase shaped, base truncate; calyx plates gently convex or concave, smooth sculpturing, strongly convex along ray plates.

Basal circlet visible in side view, truncate proximally with proximal ridge, approximately $19 \%$ of calyx height; basal plates concave, total number unknown.

Radial circlet approximately $24 \%$ of calyx height, radial plates presumably five, hexagonal, as wide as high. Radial facets with fixed first primibrachials, but approximately $40 \%$ of distal width of radial plate and declivate.

Normal interrays very poorly preserved, depressed between ray ridges, in contact with tegmen. Presumably one large first interradial plate followed by two interradial plates; distal-most fixed interradial plates adjacent to first or second secundibrachial. Posterior interray and tegmen unknown.

First primibrachial fixed, tetragonal, approximately as wide as high, much smaller than radial plates; second primibrachial fixed, axillary, pentagonal. First secundibrachial fixed, tetragonal; second secundibrachial tetragonal, at least partially fixed. Small fixed intrabrachial plates in center of ray begin adjacent to secundibrachials but not in contact with primaxil.

Free arms 10, atomous. Third secundibrachial free, cuneate uniserial, bearing stout pinnule abaxially. Remainder of free brachials cuneate uniserial, aborally convex, pinnulate. Pinnules long, stout.

Column circular, holomeric, heteromorphic. In proxistele, columnal latera convex, various numbers of internodals. Column fully developed in mesistele with pattern of N3231323; epifacet of nodals greatly expanded such that nodal diameter twice the diameter of internodals; internodal columnals with convex latera. Lumen and columnal facets unknown.

Etymology.-Hispaniensis, in reference to the Spanish origin of the specimen.

Measurements.-Holotype: crown height, 13.6; calyx height, 3.9; calyx maximum width, 3.7; proximal basal circlet width, 1.2; basal circlet height, 0.95 ; radial circlet height, 1.4; column 
height, $7.4 *$ (measurements in millimeters, *incomplete or specimen crushed).

Remarks.-The relatively small calyx, three plates above the primanal, relatively numerous fixed brachials, three unequal basal plates, and 10 cuneate arms with prominent pinnules ally this taxon with Eopatelliocrinus. Species characters in Eopatelliocrinus include shape of the calyx, relative size, presence or absence of a proximal rim on the basal circlet, calyx plate sculpturing, presence or absence of ray ridge extending onto fixed brachials, nature of arms, and shape of proximal column. E. hispaniensis n. sp. is distinct from other species in this genus with a medium cone-shaped calyx, the calyx relatively small, a rim on the proximal basal circlet, smooth calyx plate sculpturing with plate triple junctions not depressed, ray ridges that continue onto fixed brachials, robust and gently tapering arms, and a circular proximal column. By contrast, E. latibrachiatus Brower, 1973 has a medium globe-shaped calyx, the calyx relatively small, rim absent on the proximal basal circlet, broadly stellate plate sculpturing with plate triple junctions depressed, ray ridges that do not continue onto fixed brachials, slender arms that taper sharply in distal third, and a weakly pentalobate proximal column; E. ornatus Brower, 1994 has a medium bowl-shaped calyx, the calyx relatively small, a rim on the proximal basal circlet, broad and fine stellate calyx plate sculpturing, plate triple junctions not depressed, ray ridges that continue onto fixed brachials, slender and gently tapering arms, and a circular distal column; and E. scyphogracilis has a medium cone-shaped calyx, the calyx relatively large, a rim on the proximal basal circlet, weak stellate calyx plate sculpturing, plate triple junctions not depressed, ray ridges that continue onto fixed brachials, slender and gently tapering arms, and a circular distal column.

Subclass Cladida Moore and Laudon, 1943

Order Dendrocrinida Bather, 1899

Superfamily Mastigocrinoidea Bather, 1899

Family Thenarocrinidae Jaekel, 1918

Genus Picassocrinus new genus

Type species.—Picassocrinus villasi new species, by monotypy.

Diagnosis.-Thenarocrinid with relatively small crown, three anal plates in sutural contact above the anal $\mathrm{X}$, arms branch twice isotomously, and brachials as high as wide.

Etymology.-Picassocrinus, in recognition of the Spanish abstract artist Pablo Picasso and in reference to the atypical plating of the posterior interray.

\section{Picassocrinus villasi new species}

Figures 4.8, 5.8-5.10

2015a cladid crinoid in Zamora, et al., p. 237, fig. 19B.

Holotype.-The holotype, MPZ2016/83, part and counterpart, is the only known specimen of this species.

Diagnosis.—As for genus, by monotypy.
Occurrence.-Fombuena Formation, upper middle Berounian (lower Katian, Upper Ordovician), near Fombuena (Zaragoza province), Spain; Locality 2.

Description.-Crown small; aboral cup medium cone shaped, width to height ratio approximately 1.0, plates gently convex, smooth.

Infrabasals five, equal in size, approximately as high as wide; infrabasal circlet approximately $28 \%$ of aboral cup height, base truncate. Basals probably five, hexagonal, approximately as high as wide, approximately the same size as radial plates; basal circlet approximately 34\% of aboral cup height. Radials five, pentagonal, markedly convex distally emphasizing radial position on plate, wider than high; radial circlet approximately $38 \%$ of aboral cup height. Radial facets angustary, declivate, occupy approximately $33 \%$ of distal radial plate width; radial facet topography not known.

Three anal plates in cup; radianal heptagonal, in sutural contact proximally with infrabasal plates, directly below $\mathrm{C}$ radial plate; anal X large, above and to left of radianal, wider than high, laterally adjacent to $\mathrm{C}$ and $\mathrm{D}$ radial plates; right tube plate partially in aboral cup. Tegmen and anal structure unknown.

Arms branch isotomously two times. First primibrachial as high as wide, sixth primibrachial axillary, primaxil as wide as high. First secundibrachials in lateral contact medially, seventh or higher secundibrachial axillary; first tertibrachials not in lateral contact medially. All brachials rectangular uniserial, aborally convex, nonaxillary brachial dimensions variable but wider than high; convex.

Column circular, holomeric, and heteromorphic; nodals alternative with one internodal. Proxistele widest immediately below aboral cup, tapers distally to mesistele where column diameter is constant as known.

Etymology.-Villasi, in recognition of Enrique Villas, who contributed much to understanding Ordovician stratigraphy of the Iberian Chains.

Measurements.-Holotype: crown height, 16.9*; aboral cup height, 4.3; aboral cup distal width, 4.3*; aboral cup proximal width, 2.4; column height, 14.2 (measurements in millimeters, *incomplete or specimen crushed).

Remarks.-Picassocrinus villasi is a relatively small crinoid, but most aspects of its morphology are well preserved. As discussed in the following, Picassocrinus has a very unusual CD interray; its column is also unusual. The proximal columnal is the widest columnal, the proxistele columnals become progressively narrow distally, and mesistele columnals appear to be basically uniform in width (not including the differences between nodals and internodals). This morphology suggests that the proxistele and mesistele were distinct column segments separated by a generating columnal (Wulff and Ausich, 1989); however, clear evidence of a generating columnal is absent. As argued by Wulff and Ausich (1989), it seems improbable that a crinoid would insert a wide columnal under that aboral cup only to have it reduce in size through ontogeny. If narrowing the width through ontogeny is not true, two possibilities remain to 
explain the column morphology in Picassocrinus villasi. First, it may have a cryptic generating columnal. Second, the rapid widening of the proximal column may record a period of very rapid growth of the crinoid crown. Additional specimens are needed to determine the exact process(es) by which this unusual column formed.

Picassocrinus has a unique posterior interray among Ordovician cladids, and only one Silurian crinoid, Thenarocrinus Bather, 1890 (Wenlockian, Avalonia and Baltica paleocontinents), is known with the same posterior plating. These two crinoids have a single large radianal plate that is in sutural contact with the infrabasal circlet below. This radianal plate separates the BC and CD basal plates, resulting in a basal circlet comprised of six subequal plates. Previously, Thenarocrinus was the only member of the Thenarocrinidae. An indication of the unusual nature of the posterior of this crinoid is that Thenarocrinus was interpreted differently in different portions of the work by Moore and Teichert (1978). Moore and Lane (1978a, fig. 394) depicted this large anal plate as a fused inferradianal and superradianal, whereas Moore and Lane (1978b, fig. 403) interpreted this plate as a simple radianal plate.

The only other Ordovician or Silurian crinoids with the radianal plate in sutural contact with the infrabasal circlet are crinoids such as Archaetaxocrinus Lewis, 1981; Compagicrinus Jobson and Paul, 1979; and Elpasocrinus Sprinkle and Wahlman, 1994. All of these crinoids have a compound radianal. Curiously, the Moore and Lane (1978a) interpretation indicates that the Thenarocrinus radianal is a fused inferradianal and superradianal. Three hypotheses can be posed for this plate: (1) an expanded inferradianal and absent superradianal; (2) an expanded superradianal and absent inferradianal; or (3) as suggested by Moore and Lane (1978a), the inferradianal and superradianal are fused. Data do not presently exist to enable choosing among these alternatives.

Picassocrinus is tentatively placed in the Thenarocrinidae on the basis of the unique CD plating. Detailed phylogenetic analysis, which is beyond the scope of this study, would be required to determine whether this unusual $\mathrm{CD}$ plating defines an early Paleozoic clade or whether this condition was independently derived in Thenarocrinus and Picassocrinus.

Picassocrinus is distinguished from Thenarocrinus on the basis of the relative size of the crown, plating above the anal X plate, arm branching, and brachial morphology. Picassocrinus has a relatively small crown, three anal plates in sutural contact above the anal $\mathrm{X}$, arms that branch twice isotomously, and brachials that are as high as wide. By contrast, Thenarocrinus has a relatively large crown, one anal plate in sutural contact above the anal $\mathrm{X}$, arms that branch numerous times with poor isotomy, and brachials that are much wider than high.

Subclass Disparida Moore and Laudon, 1943

Order Maennilicrinida Ausich, 1998b

Family Maennilicrinidae Ausich, 1998b

Genus Heviacrinus Gil Cid, Domínguez Alonso, and Silván Pobes, 1996

Type species.-Heviacrinus melendezi Gil Cid, Domínguez Alonso, and Silván Pobes, 1996; by monotypy.

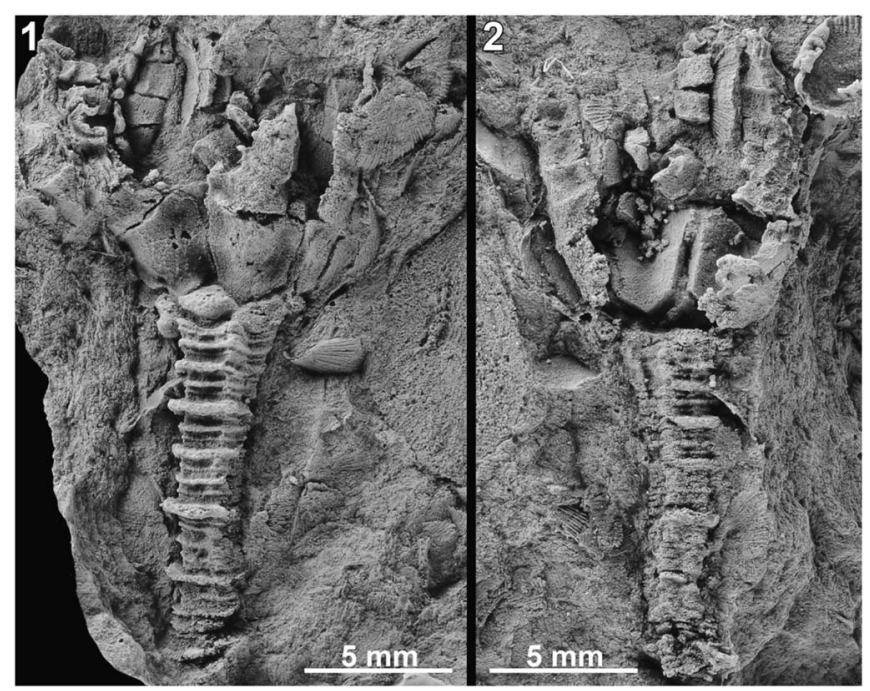

Figure 7. Heviacrinus melendezi from the Castillejo Formation of Spain, (1) part and (2) counterpart. Lateral view of partial calyx and proximal stem, MPZ2016/106.

Other species.-H. tromelini Lefebvre et al., 2015.

Heviacrinus melendezi Gil Cid, Domínguez Alonso, and Silván Pobes, 1996

Figure 7.1, 7.2

2015a Heviacrinus sp., Zamora et al., fig. 17.

Holotype.-MNCN-1-35384.

Occurrence.-Previously, H. melendezi had been reported from Guindo Shales Formation (upper lower Dobrotivian, upper Darriwilian, Spain), Navas de Estena Shales (lower Dobrotivian, upper Darriwilian, Spain), Rio Shales Formation (lower upper Oretanian, upper Darriwilian, Spain), several Darriwilian formations in the Armorican Massif of France (Lefebvre et al., 2015), and possibly from the Valongo Formation (upper Arenigian-lower Oretanian, Darriwilian, Portugal). The occurrence reported here is from the Castillejo Formation (upper Dobrotivian, upper Darriwilian to lower Sandbian), La Peña del Tormo section, near Fombuena (Zaragoza province), northeastern Spain; Locality 3.

Materials.-The new specimen, MPZ2006/106, part and counterpart.

Remarks.-A single specimen of Heviacrinus is reported from the Castillejo Formation (Darriwilian) of northern Spain. This specimen is a mold of a partial crown with some of the column and arms attached (Fig. 7). Illustrated as Heviacrinus sp. in Zamora et al. (2015a, fig. 17), this crinoid is assigned to H. melendezi herein.

\section{Acknowledgments}

This work is dedicated to the pioneering paleontologists W. Hamman, E. Villas, and J.C. Gutiérrez-Marco, who have dedicated their time and efforts to understanding the Ordovician 
rocks and fossils of the Iberian Chains. We thank the amateur collector F. Gracia for help with fieldwork. One of the beds containing the crinoids was discovered by F. Gahn and J. Savill during the celebration of the Progress in Echinoderm Palaeobiology meeting field trip. We thank S. Rozhnov, S. Sheffield, and an anonymous reviewer for providing feedback on the manuscript and I. Rahman for helpful comments. SZ is funded by a Ramón y Cajal Grant (RYC2012-10576) and projects CGL2012-39471 and CGL2013-48877 from the Spanish Ministry of Economy and Competitiveness; WIA and SRC were funded in part by the National Science Foundation (DEB: 1036416); SRC was also funded through a student travel grant from the Palaeontological Association and a Presidential Fellowship through The Ohio State University.

\section{References}

Angelin, N.P., 1878, Iconographia Crinoideorum in stratis Sueciae Siluricis fossilium: Holmiae, Samson and Wallin, $62 \mathrm{p}$.

Ausich, W.I., 1985, New crinoids and revision of the superfamily Glyptocrinacea (early Silurian, Ohio): Journal of Paleontology, v. 59, p. 793-808.

Ausich, W.I., 1986, Early Silurian rhodocrinitacean crinoids (Brassfield Formation, Ohio): Journal of Paleontology, v. 60, p. 84-106.

Ausich, W.I., 1998a, Early phylogeny and subclass division of the Crinoidea (phylum Echinodermata): Journal of Paleontology, v. 72, p. $499-510$.

Ausich, W.I., 1998b, Phylogeny of Arenig to Caradoc crinoids (Phylum Echinodermata) and suprageneric classification of the Crinoidea: The University of Kansas Paleontological Contributions, new series, v. 9, p. 1-36.

Ausich, W.I., and Deline, B., 2012, Macroevolutionary transition in crinoids following the Late Ordovician extinction event (Ordovician to early Silurian): Palaeogeography, Palaeoclimatology, Palaeoecology, v. $361-362$, p. $38-48$.

Ausich, W.I., and Kammer, T.W., 2011, The study of crinoids during the 20th century and the challenges of the 21st century: Journal of Paleontology, v. 75, p. 1161-1173.

Ausich, W.I., Kammer, T.W., and Baumiller, T.K., 1994, Demise of the middle Paleozoic crinoid fauna: A single extinction event or rapid faunal turnover?: Paleobiology, v. 20, p. 345-361.

Ausich, W.I., Gil Cid, D., and Domínquez Alonso, P., 2002, Ordovician [Dobrotivian (Llandeillian Stage) to Ashgill] Crinoids (Phylum Echinodermata) from the Montes de Toledo and Sierra Morena, Spain with implications for paleogeography of peri-Gondwana: Journal of Paleontology, v. 76, p. 975-992.

Ausich, W.I., Sá, A.A., and Gutiérrez-Marco, J.C., 2007, New and revised occurrences of Ordovician crinoids from southwestern Europe: Journal of Paleontology, v. 81, p. 1374-1383.

Babin, C., and Mélou, M., 1972, Mollusques Bivalves et Brachiopodes des "schistes de Raguenez" (Ordovicien supérieur du Finistère); conséquences stratigraphiques et paléobiogéographiques: Annales de la Société géologique du Nord, v. 92, p. 79-94.

Barrande, J., 1867, Système silurien du centre de la Bohême, Volume 3, Ptéropodes: Prague and Paris, J. Barrande, 179 p.

Bather, F.A., 1890, British fossil crinoids. II. The classification of the Inadunata: Annals and Magazine of Natural History, v. 5, p. 310-334.

Bather, F.A., 1899, A phylogenetic classification of the Pelmatozoa: British Association for the Advancement of Science, v. 1898, p. 916-923.

Baumiller, T.K., 1994, Patterns of dominance and extinction in the record of Paleozoic crinoids, in David, B., Guille, A., Féral, J.P., and Roux, M., eds., Echinoderms Through Time (Echinoderms Dijon): Rotterdam, A. A. Balkema, p. 193-198.

Billings, E., 1857, New species of fossils from Silurian rocks of Canada: Canada Geological Survey, Report of Progress 1853-1856, Report for the year 1856, p. 247-345.

Botting, J.P., 2003, Llanvirn (Middle Ordovician) echinoderms from the Llandegley Rocks, central Wales: Palaeontology, v. 46, p. 685-708.

Brett, C.E., Moffat, H.A., and Taylor, W.L., 1997, Echinoderm taphonomy, taphofacies, and Lagerstätten: Paleontological Society Papers, v. 3, p. $147-190$.

Brower, J.C., 1973, Crinoids from the Girardeau Limestone (Ordovician): Palaeontographica Americana, v. 7, p. 263-499.
Brower, J.C., 1994, Camerate crinoids from the Middle Ordovician (Galena Group, Dunleith Formation) of northern Iowa and southern Minnesota: Journal of Paleontology, v. 68, p. 570-599.

Carls, P., 1975, The Ordovician of the Eastern Iberian Chains near Fombuena and Luesma: Neues Jahrbuch für Geologie und Paläontologie Abhandlungen, v. 152, p. 127-146.

Chauvel, J., 1936, Note sur les cystidées armoricaines: genres Calix et Pachycalyx: Société géologique et minéralogique de Bretagne, Comptes Rendus Sommaires des Séances, v. 2, p. 1-4.

Chauvel, J., and Meléndez, B., 1986, Note complémentaire sur les échinodermes ordoviciens de Sierra Morena: Estudios Geológicos, v. 42, p. $451-459$.

Colmenar, J., 2015, The arrival of brachiopods of the Nicolella Community to the Mediterranean margin of Gondwana during the Late Ordovician: Palaeogeographical and palaeoecological implications: Palaeogeography, Palaeoclimatology, Palaeoecology, v. 428, p. 12-20.

Colmenar, J., Villas, E., and Vizcaino, D., 2013, Upper Ordovician brachiopods from the Montagne Noire (France): Endemic Gondwanan predecessors of Prehirnantian low-latitude immigrants: Bulletin of Geosciences, v. 8, p. 153-174.

Correia, P., and Loureiro, J., 2009, Novas ocorrências de crinóides no Darriwiliano (Ordovícico Médio) do anticlinal de Valongo (NW de Portugal): Paleolusitana, v. 1, p. 141-150.

Donovan, S.K., and Savill, J.J., 1988, Ramseyocrinus (Crinoidea) from the Arenig of Morocco: Journal of Paleontology, v. 62, p. 283-285.

Donovan, S.K., Miller, C.G., Sansom, I.J., Heward, A.P., and Schreures, J., 2011, A Laurentian Iocrinus Hall (Crinoidea, Disparida) in the Dapingian and Darriwilian (Middle Ordovician, Arenig) of Oman: Journal of Paleontology, v. 54, p. 525-533.

Eckert, J.D., 1988, Late Ordovician extinction of North American and British crinoids: Lethaia, v. 21, p. 147-167.

Forbes, E., 1848, On the Cystideae of the Silurian rocks of the British Isles: Memoir of the Geological Survey of the United Kingdom, v. 2, p. 483-538

Fortey, R.A., and Cocks, L.R.M., 2005, Late Ordovician global warming-The Boda event: Geology, v. 33, p. 405-408.

Gahn, F.J., 2015, Homological and phylogenetic implications of a disparid-like posterior interray among Lower Ordovician camerate crinoids, in Zamora, S., and Rábano, I., eds., Progress in Echinoderm Palaeobiology: Cuadernos del museo Geominero, 19, Instituto Geológico y Minero de España, p. 59-65.

Gil Cid, M.D., Domínguez Alonso, P., and Silván Pobes, E., 1996, Reconstrucción y modo vida de Heviacrinus melendezi nov. gen. nov. sp. (Disparida Iocrinidae), primer crinoide descrito para el Ordovícico medio de los Montes de Toledo (España): Revista de la Sociedad Geológica de España, v. 9, p. 19-27.

Gil Cid, M.D., Domínguez Alonso, P., and Silván Pobes, E., 1998, Coralcrinus sarachagae gen. nov. sp. nov., primer crinoide (Disparida, Inadunata) descrito en el Ordovícico medio de Sierra Morena: Coloquios de paleontología, v. 49, p. 115-128.

Guensburg, T.E., 1984, Echinodermata of the Middle Ordovician Lebanon Limestone, Central Tennessee: Ithaca, New York, Paleontological Research Institution, $100 \mathrm{p}$.

Guensburg, T.E., and Waisfeld, B.G., 2015, South America's earliest (Ordovician, Floian) crinoids: Journal of Paleontology, v. 89, p. 622-630.

Gutiérrez-Marco, J.C., 1986, Graptolitos del Ordovícico español [Ph.D. dissertation]: Universidad Complutense de Madrid, $701 \mathrm{p}$.

Gutiérrez-Marco, J.C., Chauvel, J., and Meléndez, B., 1996, Nuevos equinodermos (cistideos y blastozoos) del Ordovícico de la Cordillera Iberica (NE Espana): Revista Española de Paleontología, v. 11, p. 100-119.

Gutiérrez-Marco, J.C., Robardet, M., Rábano, I., Sarmiento, G.N., San José, M. Á., Herranz Araujo, P., and Pieren Pidal, A.P., 2002, Ordovician, in Gibbons, W., and Moreno, M.T., eds., The Geology of Spain: Geological Society of London, p. 31-49.

Gutiérrez-Marco, J.C., Herranz, P., Pieren, A., Rábano, I., Sarmiento, G.N., San José, M.A., de, Barnolas, A., and Villas, E., 2005, El margen pasivo Ordovícico-Silúrico, in Vera, J.A., ed., Geología de España: Madrid, SGE-IGME, p. 473-475.

Gutiérrez-Marco, J.C., Sá, A.A., Rábano, I., Sarmiento, G.N., García-Bellido D.C., Bernárdez, E., Lorenzo, S., Villas, E., Jiménez-Sánchez, A., Colmenar, J., and Zamora, S., 2015, Iberian Ordovician and its international correlation: Stratigraphy, v. 12, p. 107-108.

Hall, J., 1866, Descriptions of new species of Crinoidea and other fossils from the lower Silurian strata of the age of the Hudson-River Group and Trenton Limestone: Albany, 17 p. (privately distributed preprint).

Hammann, W., 1992, The Ordovician trilobites from the Iberian Chains in the province of Aragón, NE Spain. Pt. I. The trilobites of the Cystoid Limestone (Ashgill Series): Beringeria, v. 6, p. 1-219.

Hammann, W., Robardet, M., and Romano, W., 1982, The Ordovician System in southwestern Europe (France, Spain, and Portugal): Correlation chart and explanatory notes: IUGS Publications, v. 11, p. 1-46. 
Haugh, B.N., 1979, Late Ordovician channel-dwelling crinoids from southern Ontario, Canada: American Museum Novitates, v. 2665, p. 1-25.

Jaekel, O., 1918, Phylogenie und System der Pelmatozoen: Paläeontologische Zeitschrift, v. 3, p. 1-128.

Jobson, L., and Paul, C.R.C., 1979, Compagicrinus fenestratus, a new Lower Ordovician inadunate crinoid from North Greenland: Rapport Gronlands Geologic Undersog, v. 91, p. 71-81.

Kammer, T.W., and Ausich, W.I., 2006, The "Age of Crinoids": A Mississippian biodiversity spike coincident with widespread carbonate ramps: PALAOIS, v. 21, p. 238-248.

Kolata, D.R., 1982, Camerates, in Sprinkle, J., ed., Echinoderm faunas from the Bromide Formation (Middle Ordovician) of Oklahoma: The University of Kansas Paleontological Contributions, Monograph, v. 1, p. $170-205$.

Kolb, S., 1978, Erläuterungen zur geologischen Kartierung des Gebietes S. Cerveruela in den Östlichen Iberischen Ketten (NE- Spanien) [Ph.D. thesis]: Universität Würzburg, $122 \mathrm{p}$.

Lefebvre, B., and Fatka, O., 2003, Palaeogeographical and palaeoecological aspects of the Cambro-Ordovician radiation of echinoderms in Gondwanan Africa and peri-Gondwanan Europe: Palaeogeography, Palaeoclimatology, Palaeoecology, v. 195, p. 73-97.

Lefebvre, B., Sumrall, C.D., Shroat-Lewis, R.A., Riech, M., Webster, G.D., Hunter, A.W., Nardin, E., Rhoznov, S.V., Guensburg, T.E., Touzeau, A., Noailles, F., and Sprinkle, J., 2013, Palaeobiogeography of Ordovician echinoderms, in Harper, D.A.T., and Servais, T., eds., Early Palaeozoic Biogeography and Palaeogeography: Geological Society, London, Memoirs. 38, p. 173-198.

Lefebvre, B., Ausich, W.I., Clausen, S., Courville, P., Kundura, J.-P., Legrain, X., Régnault, S., and Roussel, P., 2015, A review of Ordovician crinoids from France: New data from the Darriwilian of the Armorican Massif and palaeobiogeographic implications: Annales de Paléontologie, v. 101 , p. $301-312$

Le Menn, J., and Spjeldnaes, N., 1996, Un nouveau crinöide Dimerocrinitidae (Camerate, Diplobathrida) de l'Ordovicien supérieur du Maroc: Rosfacrinus robustus nov. gen., nov. sp.: Geobios, v. 29, p. 341-351.

Lewis, R.D., 1981, Archaetaxocrinus, new genus, the earliest known flexible crinoid (Whiterockian) and its phylogenetic implications: Journal of Paleontology, v. 55, p. 227-238.

Lotze, F., 1929, Stratigraphie und Tektonik des Keltiberischen Grundgebirges (Spanien): Abhandlungen der Gesellschaft für Wissenschaften Göttingen, Mathematisch-Physikalische Klasse, v. 14, p. 1-320.

Meléndez, B., 1944, Contribución al estudio del Paleozoico aragonés: Trabajos del Instituto de Ciencias Naturales José de Acosta, Serie Geológica, v. 3, p. $1-149$.

Mélou, M., 1975, Le genre Heterorthina (Brachiopoda, Orthida) dans la formation des Schistes de Postolonnec (Ordovicien) Finistère, France: Geobios, v. 8, p. 191-208.

Miller, J.S., 1821, A Natural History of the Crinoidea, or Lily-Shaped Animals; with Observations on the Genera, Asteria, Euryale, Comatula and Marsupites: Bristol, England, Bryan \& Co., 150 p.

Moore, R.C., 1952, Crinoids, in Moore, R.C., Lalicker, C.G., and Fischer, A.G., eds., Invertebrate Fossils: New York, McGraw-Hill, p. 604-652.

Moore, R.C., and Lane, N.G., 1978a, Superfamily Dendrocrinacea Wachsmuth and Springer, 1886, in Moore, R.C., and Teichert, C., eds., Treatise on Invertebrate Paleontology, Pt. T. Echinodermata 2: Lawrence, Geological Society of America and University of Kansas Press, p. T607-T681.

Moore, R.C., and Lane, N.G., 1978b, Superfamily Matigocrinacea Jaekel, 1918, in Moore, R.C., and Teichert, C., eds., Treatise on Invertebrate Paleontology, Pt. T. Echinodermata 2: Lawrence, Geological Society of America and University of Kansas Press, p. T681-T626.

Moore, R.C., and Laudon, L.R., 1943, Evolution and classification of Paleozoic crinoids: Geological Society of America Special Paper, v. 46, 151 p.

Moore, R.C., and Teichert, C., eds., 1978, Treatise on Invertebrate Paleontology, Pt. T. Echinodermata 2: Lawrence, Geological Society of America and University of Kansas Press, $1027 \mathrm{p}$.

Paris, F., 1979, Les Chitinozoaires de la Formation de Louredo, Ordovicien Supérieur du Synclinal de Buçaco (Portugal): Palaeontographica A, v. 164 , p. 24-51.

Paris, F., 1981, Les Chitinozoaires dans le Paléozoique du sud-ouest de l'Europe: cadre géologique, tude systématique, biostratigraphie: Mémoires de la Société Géologique et Minéralogique de Bretagne, v. 26, p. 1-496.

Paul, C.R.C., 1976, Palaeogeography of primitive echinoderms in the Ordovician, in Bassett, M.G., ed., The Ordovician System: Proceedings of a Palaeontological Association Symposium: Birmingham and Cardiff, The University of Wales Press and National Museum of Wales, p. 553-574.

Peters, S.E., and Ausich, W.I., 2008, A sampling-adjusted macroevolutionary history for Ordovician-early Silurian crinoids: Paleobiology, v. 34, p. $104-116$.
Rasmussen, C.M.Ø., and Harper, D.A.T., 2011, Interrogation of distributional data for the End Ordovician crisis interval: Where did disaster strike? Geological Journal, v. 46, p. 478-500.

Roemer, C.F., 1854-1855, Erste Periode, Kohlen-Gebirge, in Brown, H.G., ed., Lethaea Geognostica, 3rd ed., v. 2: E. Schweizerbart, Stuttgart, p. 788 .

Sarmiento, G.N., 2002, Lower Palaeozoic of the Iberian Cordillera, in García-López, S., and Bastida, F., eds., Palaeozoic conodonts from Northern Spain: Instituto Geológico y Minero de España, serie Cuadernos del Museo Geominero, v. 1, p. 281-297.

Sarmiento, G.N., Gutiérrez-Marco, J.C., and Rábano, I., 1995, A biostratigraphical approach to the Middle Ordovician conodonts from Spain, in Cooper, J.D., Droser, M.L., and Finney, S.E., eds., Ordovician Odyssey, Pacific Section Society for Sedimentary Geology, Book 77: Fullerton, p. 61-64.

Sowerby, J.C., and Murchison, R.I., 1839, The Silurian System, founded on geological researches in the counties of Salop, Hereford, Radnor, Montgomery, Caermarthen, Brecon, Pembroke, Monmouth, Gloucester, Worcester, and Stafford; with descriptions of the coalfields and overlying formations: London, John Murray, p. 786.

Sprinkle, J., and Guensburg, T.E., 2004, Crinozoan, blastozoan, echinozoan, asterozoan, and homalozoan echinoderms, in Webby, B.D., Paris, F., Droser, M.L., and Percival, I.G., eds., The Great Ordovician Biodiversification Event: New York, Columbia University Press, p. 266-280.

Sprinkle, J., and Wahlman, G.P., 1994, New echinoderms from the Early Ordovician of west Texas: Journal of Paleontology, v. 68 , p. 324-338.

Strimple, H.L., and Watkins, W.T., 1955, New Ordovician echinoderms: Journal of the Washington Academy of Science, v. 45, p. 347-353.

Sumrall, C.D., Deline, B., Colmenar, J., Sheffield, S.L., and Zamora, S., 2015 , New data on Late Ordovician (Katian) echinoderms from Sardinia, Italy, in Zamora, S., and Rábano, I., eds., Progress in Echinoderm Palaeobiology: Cuadernos del museo Geominero, 19, Instituto Geológico y Minero de España, p. 175-180.

Ubaghs, G., 1969, Aethocrinus moorei Ubaghs, n. gen., n. sp., le plus ancien crinoïde dicyclique connu: The University of Kansas Paleontological Contributions, v. 38, p. 1-25.

Ubaghs, G., 1972, More about Aethocrinus moorei Ubaghs, the oldest known dicyclic crinoid: Journal of Paleontology, v. 46, p. 773-775.

Ubaghs, G., 1978, General morphology, in Moore, R.C., and Teichert, C., eds., Treatise on Invertebrate Paleontology, Pt. T. Echinodermata 2: Lawrence, Geological Society of America and University of Kansas Press, p. T58-T216.

Villas, E., 1983, Las formaciones del Ordovícico Medio y Superior de las Cadenas Ibéricas y su fauna de braquiópodos: Estudios Geológicos, v. 39, p. 359-377.

Villas, E., 1985, Braquiópodos del Ordovícico Medio y Superior de las Cadenas Ibéricas Orientales: Memorias del Museo Paleontológico de la Universidad de Zaragoza, v. 1, 223 p.

Villas, E., 1992, New Caradoc brachiopods from the Iberian Chains (Northeastern Spain) and their stratigraphic significance: Journal of Paleontology, v. 66, p. $772-793$.

Villas, E., 1995, Caradoc through early Ashgill brachiopods from the CentralIberian zone (Central Spain): Geobios, v. 28, p. 49-84.

Villas, E., Vizcaïno, D., Alvaro, J.J., Destombes, J., and Vennin, E., 2006 , Biostratigraphic control of the latest-Ordovician glaciogenic unconformity in Alnif (Eastern Anti-Atlas, Morocco) based on brachiopods: Geobios, v. 39 , p. $727-737$.

Vinassa de Regny, P., 1942, Fossili ordoviciani sardi, Part II: Atti degli Reale Accademia d'Italia, Memorie Scienze Fisiche, Matematiche et Naturale, v. 12 , p. $1025-2055$.

Wachsmuth, C., and Springer, F., 1880-1886, Revision of the Palaeocrinoidea. Proceedings of the Academy of Natural Sciences of Philadelphia Pt. I. The families Ichthyocrinidae and Cyathocrinidae (1880), p. 226-378 (separate repaged p. 1-153). Pt. II. Family Sphaeroidocrinidae, with the sub-families Platycrinidae, Rhodocrinidae, and Actinocrinidae (1881), p. 177-411 (separate repaged, p. 1-237). Pt. III, Sec. 1. Discussion of the classification and relations of the brachiate crinoids, and conclusion of the generic descriptions (1885), p. 225-364 (separate repaged, 1-138). Pt. III, Sec. 2. Discussion of the classification and relations of the brachiate crinoids, and conclusion of the generic descriptions (1886), p. 64-226 (separate repaged to continue with section 1, 139-302).

Walcott, C.D., 1883, Descriptions of new species of fossils from the Trenton Group of New York: Advance publication of New York State Museum of Natural History, Annual Report, v. 35, p. 207-214.

Webby, B.D., Paris, F., Droser, M.L., and Percival, I.G., eds., 2004, The Great Ordovician Biodiversification Event: New York, Columbia University Press, $484 \mathrm{p}$. 
Webster, G.D., and Webster, D.W., 2014, Bibliography and index of Paleozoic crinoids, coronates, and hemistreptocrinoids, 1758-2012: http://crinoids. azurewebsites.net/ (accessed May 2016).

Wolf, R., 1980, The lower and upper boundary of the Ordovician system of some selected regions (Celtiberia, Eastern Sierra Morena) in Spain: Neues Jahrbuch für Geologie und Paläontologie Abhandlungen, v. 160, p. 118-137.

Wulff, J.I., and Ausich, W.I., 1989, Growth of the xenomorphic crinoid column (Taxocrinus, Late Mississippian: Journal of Paleontology, v. 63, p. 657-662

Zamora, S., Colmenar, J., and Ausich, W.I., 2014, The echinoderm faunas from the Fombuena Formation (Upper Ordovician, Iberian Chains, Spain), in Royo-Torres, R., Verdú, F.J., and Alcalá, L., eds., XXX Jornadas de Paleontología de la Sociedad Española de Paleontología: ¡Fundamental. v. 24, p. $257-259$.
Zamora, S., Álvaro, J.J., Arbizu, M., Colmenar, J., Esteve, J., FernándezMartínez, E., Fernández, L.P., Gutiérrez-Marco, J.C., Suárez, Andres, J.L., Villas, E., and Waters, J., 2015a, Field trip: Palaeozoic echinoderms from northern Spain: Progress in Echinoderm Palaeobiology, Cadernos del Museo Geominero, Madrid, Instituto Geológico y Minero de España, v. 19, p. $209-288$.

Zamora, S., Rahman, I.A., and Ausich, W.I., 2015b, A new iocrinid crinoid (Disparida) from the Ordovician (Darriwilian) of Morocco: PeerJ, v. 3 , e1450, 19 p. doi: 10.7717/peerj. 1450 .

Accepted 22 August 2016 